\title{
Speed or deliberation: a comparison of post-disaster recovery in Japan, Turkey, and Chile
}

Stephen Platt Chairman, Cambridge Architectural Research Limited, United Kingdom, and Emily So Senior Lecturer, Department of Architecture, University of Cambridge, United Kingdom

This paper compares recovery in the wake of three recent earthquakes: the Great East Japan Earthquake in March 2011; the Van earthquake in Turkey in October 2011; and the Maule earthquake in Chile in February 2010. The authors visited all three locations approximately 12-18 months after the incidents and interviewed earthquake specialists, disaster managers, urban planners, and local authorities. A key challenge to post-disaster recovery planning is balancing speed and deliberation. While affected communities must rebuild as quickly as possible, they must also seek to maximise the opportunities for improvement that disasters provide. The three case studies bring this dilemma into stark relief, as recovery was respectively slow, fast, and just right in the aftermath of the events: the Government of Japan adopted a deliberate approach to recovery and reconstruction; speed was of the essence in Turkey; and an effective balance between speed and deliberation was achieved in Chile.

Keywords: earthquake, recovery, resilience, tsunami, urban planning

\section{Introduction}

Alexander (2013) suggests that post-disaster planning has three main aims: (i) the timely restoration of normal activities and living conditions: (ii) the protection of the community against the future impact of hazards; and (iii) the formulation and achievement of common objectives among the parties involved. Following disasters, governments often clamour to reduce risk quickly, to rebuild communities, and to reinstate permanence (Comfort, 2005). This urgent pressure to address complex, difficult decisions can lead to reactive policies that may increase the long-term vulnerability of affected populations (Ingram et al., 2006). Olshansky (2006) underlines the importance of planning and the need to balance speed and deliberation in post-disaster recovery, which inevitably witnesses tension between the two. Speed is crucial to keep businesses functioning, to rebuild infrastructure, and to supply temporary and permanent housing for survivors, but there is also a 'window of opportunity' in which to introduce change.

Ingram et al. (2006) found that, after the Indian Ocean tsunami of December 2004, a hastily designed coastal buffer zone policy in Sri Lanka resulted in the massive relocation of the affected population and in economic, environmental, and social problems that threaten the well-being of these coastal communities. Lloyd-Jones (2007) 
made an analogous point while commenting on post-tsunami recovery in the state of Tamil Nadu in south India. Families that traditionally depended on fishing were opposed to relocation to new villages some distance from the coast. In addition, some of the newly reconstructed houses remained unoccupied because they failed to meet basic needs and to accommodate cultural practices, or because they were in the wrong place. Similar issues manifested themselves in Thailand (Brown, Platt, and Bevington, 20IO): people in the village of Ban Nam Khem whose livelihood depended on fishing had been moved inland to unpopular government and non-governmental organisation (NGO)-sponsored housing developments. Some families were, however, returning to the old centre and rebuilding. The urge to resettle people away from the coast has created tensions between immediate concern of another tsunami, a relatively rare phenomenon in the Indian Ocean, and long-term well-being, threatening coastal livelihoods and exposing people to other more frequent hazards, such as flooding.

\section{Methodology}

The approach adopted in the three case studies reported here-the Great East Japan Earthquake in March 20II, the Van earthquake in eastern Turkey in October 2OII, and the Maule earthquake in Chile in February 2010-is principally ethnographic. ${ }^{\mathrm{I}}$ The studies were part of a larger project investigating recovery after major earthquakerelated disasters in Io countries (Chile, China, Iran, Italy, Japan, New Zealand, Pakistan, Thailand, Turkey, and the United States), the objective of which was to identify commonalities and to define the critical factors in improving resilience and recovery. The key to this has been to try to distinguish between what is specific to each event or country and general lessons that can be applied in other places. The affected areas were visited, typically I2-I 8 months after the incident, and the main actors were interviewed, including: politicians and local governors; architects, engineers, planners, and scientists; personnel in local government offices, central government ministries, special disaster authorities, and civil defence and emergency response entities; business people; members of chambers of commerce, voluntary organisations, and local NGOs; and community leaders and residents. It is important to note that interviews elicit both facts and subjective opinion and that these individual accounts, like all interpretations of reality, may be partial and biased. This issue was addressed by careful choice of informant, by interviewing at least 30 people in each place, by asking probing questions, and by verification through observation, crosschecking between informants, and conducting a comprehensive review of published sources.

\section{Building back better}

Disasters leave huge scars on people's lives, the economy, and infrastructure. Yet, despite the damage, there are opportunities to do some good—-to 'build back better' (Gunewadena and Schuller, 2008). Reconstruction after an earthquake is a complex 
Figure 1. Idealised recovery curve

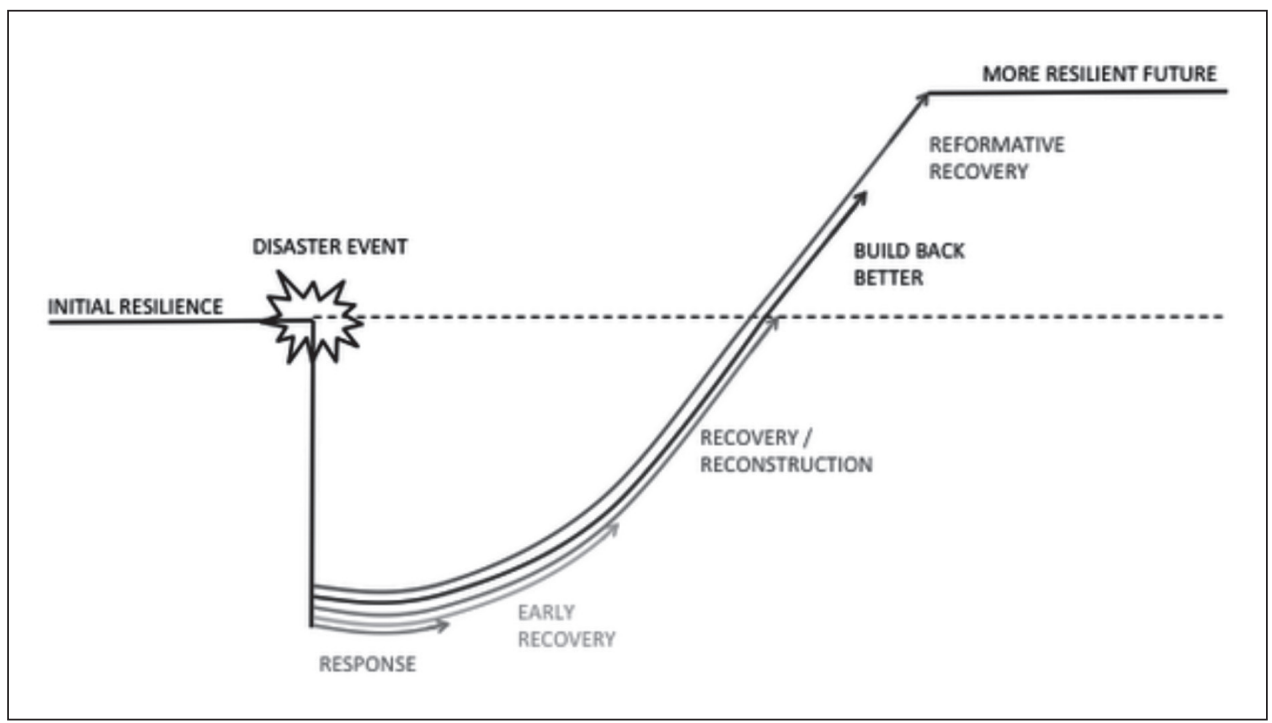

Source: Lallemant (2013, p. 1).

process entailing economic, political, and social issues as well as geotechnical considerations. However, it is also an opportunity to change how things are done. All thriving cities constantly face decisions about change, but what characterises postdisaster planning is the urgency and the seriousness of the situation (Olshansky and Johnson, 20IO).

Post-disaster recovery typically follows an S-shaped curve (see Figure I) (Lallemant, 20I3). The size of the population of an area may decrease gradually and then either recover or not, depending on the relative attractiveness of the place (Me-Bara and Valdez, 2004). Disasters can be observed in the archaeological record and recovery may take decades. Kates and Pijawka (I977) presented estimates of the time required for full population recovery after a disaster hit an urban area in ancient times (see Table I). They provided estimates of the original (pre-event) population of each location and the percentage of the population that was lost in the incident (through

Table 1. Historic earthquakes and recovery time

\begin{tabular}{|l|l|l|l|l|}
\hline Year & Location of earthquake & Population & Fatalities (\%) & Recovery time (years) \\
\hline 1746 & Lima, Peru & 37,000 & 20 & 40 \\
\hline 1755 & Lisbon, Portugal & 213,000 & 5 & 6 \\
\hline 1773 & Guatemala City, Guatemala & 34,000 & 33 & 50 \\
\hline 1775 & Kashan, Iran & 40,000 & 75 & 85 \\
\hline 1822 & Aleppo, Syria & 150,000 & 67 & 56 \\
\hline
\end{tabular}

Source: Kates and Pijawka (1977). 
death and outward migration). Recovery time is defined as the time it took for the population to reach the pre-event size. The recovery times for these historic events correlate closely with the proportion of fatalities. Nowadays, given infinitely better communication and transportation, the time taken for the population to recover to the pre-event number is shorter in most cases; an oft-quoted figure is 20 years.

Population size, though, does not tell the whole story. The population of Bam, Iran, at the time of the earthquake on 26 December 2003 was approximately 80,000 . When we visited the city in January 20I4, it was roughly I20,000, but most of the houses were unfinished and the rusting steel frames of the new houses were stark reminders of continuing recovery.

Opportunities exist in the aftermath of earthquakes to enhance hazard mitigation. Public awareness of the risk is high, and the issue is accorded high priority on political agendas (Scholl, I986). However, experience shows that current hazard response and mitigation practices often sustain communities as they are, and merely perpetuate the disaster damage cycle rather than address the root causes of the problems (Graham, I999). There is a natural tendency among survivors to want to restore their lives and communities to normal as quickly as possible (Scholl, I986), putting pressure on the authorities and inhibiting mitigation strategies and long-term planning. Nevertheless, most communities do become safer and less vulnerable to earthquakes as a result of post-disaster reconstruction (Haas et al., I977; Rubin et al., I985).

\section{The 'window of opportunity'}

If official agencies do not act quickly, many victims will begin to rebuild where and how they choose. Although speed is necessary, it is also vital to take the time to plan post-disaster reconstruction. Planning can create opportunities to improve land use and infrastructure, enhance safety, promote good design, involve citizens in decision-making, and find cost-effective solutions. But if it takes too long, it will be ineffective. Alexander (2013) cautions that reconstruction that occurs very rapidly should be treated with suspicion, for it implies that there has been a failure to consult adequately with interested parties. Time is not limitless. The worst cases, he suggests, are either those in which planners ride roughshod over local interests or those in which a conflict of interest leads to stalemate.

Reactive policies are understandable in the context of the urgent policy needs in post-disaster situations (Ingram, 2006). Relief has to be rapid and short-term recovery efforts must aim to minimise the time needed to rehouse people safely and to re-establish livelihoods. During this 'transitional' phase it is critical that communities are informed about longer-term plans in order to reduce anxiety and frustration. Long-term recovery policies require comprehensive, site-based assessments of risk and vulnerability and effective consultation with stakeholders. Long-term multi-sector strategic planning can facilitate the sustainable management of resources, supply livelihood support, strengthen infrastructure, improve urban planning and design, 
extend insurance, and enhance disaster preparedness at the national, regional, and community level.

Comerio (2013) uses two key factors, government involvement and community participation, to classify housing recovery in various counties that have experienced recent disasters (see Figure 2). While the placement of each country is based on the author's judgement, the goal is to represent the variety of approaches employed. For example, she suggests that Chile and New Zealand combined top-down and bottomup approaches, providing government leadership and funding while ensuring community empowerment in decision-making. In contrast, China and Italy assumed strong government leadership roles in supplying replacement housing but did not engage local communities in most aspects of decision-making. By comparison, Comerio (2OI3) suggests that Haiti's weak government and high levels of poverty limited recovery following the earthquake of 20 Io.

We visited seven of the nine countries (highlighted by rectangles around the name) depicted in Figure 2, as well as various others, and interviewed people involved in

Figure 2. A comparison of recovery approaches

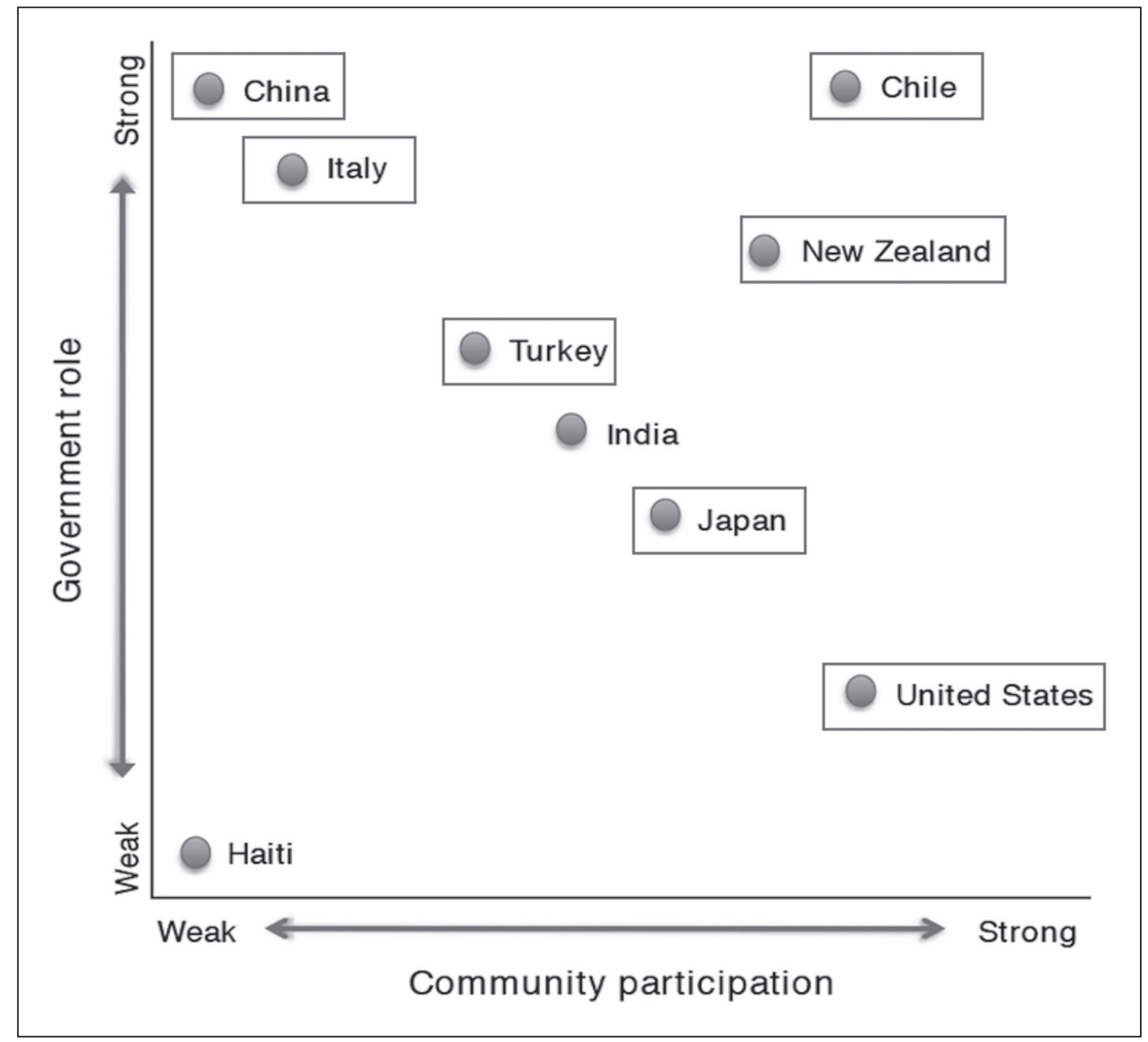

Source: Comerio (2013). 
planning recovery. Comerio's assessment of the strength of the government's role was found to be broadly correct. Her idea has been extended here in a bid to graph the window of opportunity in these nine countries and the others visited and studied by the authors.

The 'window of opportunity' for accomplishing post-disaster improvements is narrow, in many cases lasting for just I $8-36$ months after an event. Although there is little research on this topic, Comerio (I998) suggests that basic functions should be restored within two years to ensure successful recovery. This window of opportunity varies from one country to another, not so much because it is an inherent quality of disaster recovery, but rather because it is a product of the political climate in a particular country. Having to deal with an emergency moves issues higher up the policy agenda of a government (Kingdom, I995). In time, other pressing problems divert attention.

Turkey and Japan represent extremes in this regard. In Turkey, following the Van earthquake in October 20I , the window of opportunity was extremely limited in duration and extent. Post-disaster planning by the Disaster and Emergency Management Presidency (AFAD) and the various government ministries adhered to strict protocols with well-defined criteria and there were a small number of decisionmakers and little stakeholder or community involvement. The window of opportunity to do things better may have been open for six months at most.

In Japan, following the Tōhoku earthquake in March 20II, there was, by contrast, a massive concerted effort by many sections of society to come to terms with the issues and to devise safer solutions. Despite the efforts of the national government to speed up the process by providing resources and imposing deadlines, the effect was to delay reconstruction. The window of opportunity is still, to an extent, open five years after the event.

In Chile, meanwhile, following the Maule earthquake in February 20Io, the window of opportunity was open for about I8-24 months, during which architects seconded from the University of Bío Bío by the regional government worked on masterplans for the disaster-affected coastal communities and planners from the Ministry of Transport in Santiago devised a new masterplan for Concepción, the capital of the Bío Bío Region (Platt, 20I2). Subsequently, the planners who had been seconded to special teams went back to their old jobs and the government's priorities shifted with the change of government from Sebastián Piñera's centre-right Alliance for Chile to former President Michelle Bachelet's centre-left New Majority party in December 2013 (Meyer, 20I4).

Figure 3 shows the results of an attempt to estimate this window of opportunity for 12 countries (in terms of recovery and the number of months after the event). The estimates are based on fieldwork interviews in IO of the I 2 countries and an intense search of published sources. None of the papers and reports specify this time period, but, in most cases, inferences can be drawn from how long policy committees consulted and when final plans were published. 
Figure 3. The window of opportunity

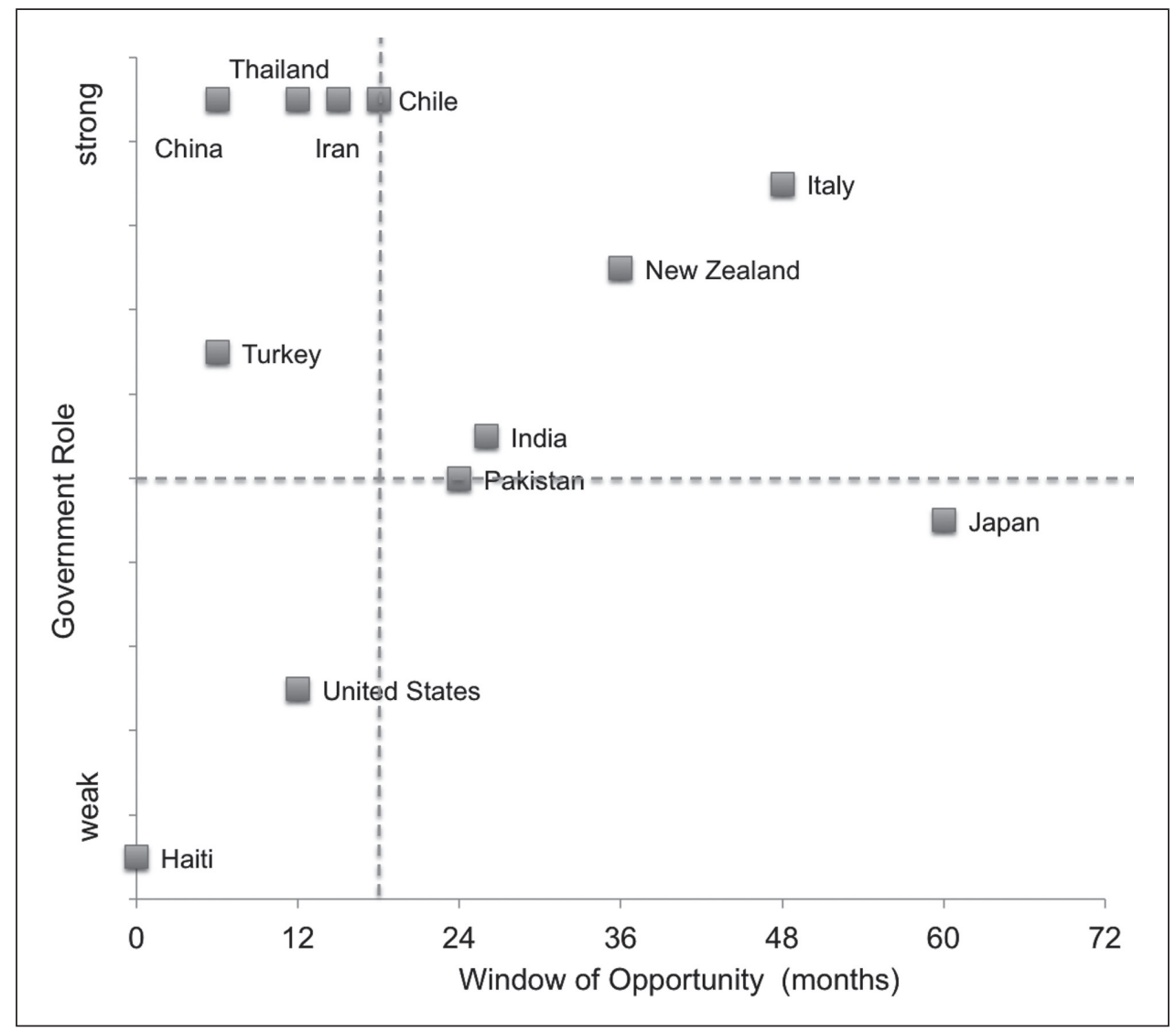

Sources: various reports and papers were used to estimate these times, but the following represent the main sources: Chile: Platt (2012); Sandoval and Gonzalez (2015); China: Huang, Zhou, and Wei (2014); Haiti: Fan (2013); India: Thiruppugazh (2001); Iran: Omidvar, Zafari, and Derakhshan (2010); Italy: OECD (2013); Japan: Matanle (2011); New Zealand: Toomey (2015); Pakistan: Kirk (2008); Thailand: Srivichai, Supharatid, and Imamura (2007); Turkey: Turan (2012); United States: Wu and Lindell (2004).

\section{Case studies}

Japan

The Great East Japan Earthquake, a magnitude 9.0 (Mw) earthquake off the coast of Tōhoku in the northeast of the country on II March 2OII, is the most expensive natural disaster recorded in the world to date. The unprecedented tsunami toppled sea defences, inundating more than 500 square kilometres of land along this shoreline. It claimed the lives of some I8,500 people, and destroyed or damaged some 400,000 and 773,000 dwellings, respectively, as well as severely damaging critical infrastructure and buildings. The impact was different on the coastal plain where there was little resistance to the wave and consequently large horizontal inundation and insignificant vertical inundation. In contrast, the Rias coast suffered a high vertical run-up owing to the amplifying effect of topography, but limited horizontal inundation (see Figure 4). 
Figure 4. Coastline, inundation, and the Tōhoku tsunami of 2011

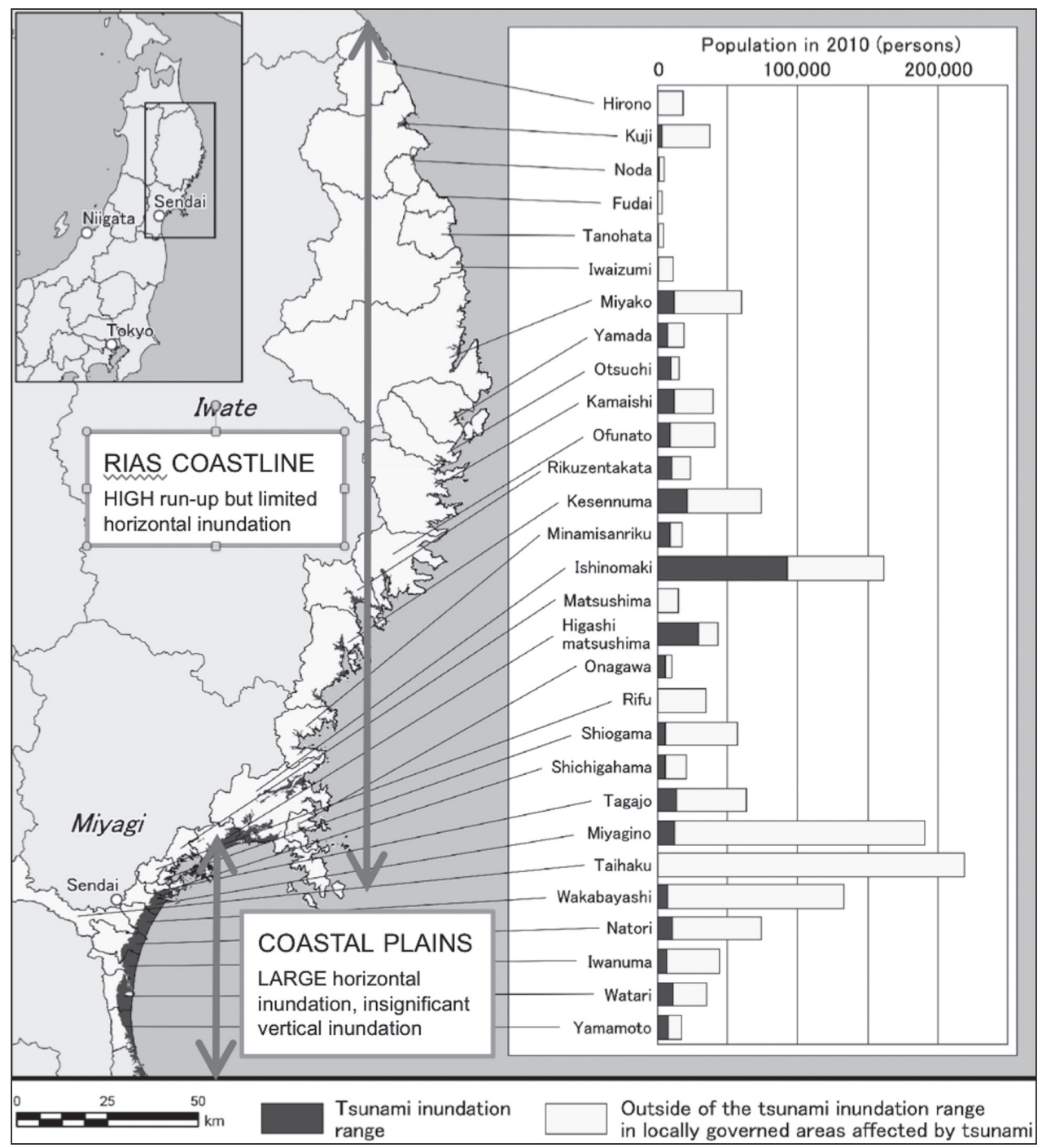

Source: authors.

Two years after the event, when we visited the area and most of the affected towns and settlements, recovery was still in its initial stages. The debris had been cleared, reconstruction work had started on one-third of destroyed embankments, and the Government of Japan was dealing with a difficult temporary housing situation. The construction of new permanent housing had taken longer than originally planned, but had allowed for longer a consultation process (Pomonis et al., 2013).

Lessons were learnt after the Great Hanshin or Kobe earthquake on I7 January I995 (Edgington, 20IO). The temporary housing viewed by the authors was of high quality. The containers were $25-30$ square metres and had two rooms plus a kitchenette and a bathroom. Some families had added porches and had planted flowers and painted 
murals. The first temporary housing units were available within eight weeks of the disaster. Within eight months, 75 per cent of the approximately 450,000 people who had sought refuge in evacuation centres had been able to move to alternative accommodation (Kawawaki et al., 20I3). The principal issue is how long people will have to remain in temporary shelter. Some 330,00o people were still in temporary accommodation and 500 remained in evacuation centres $\mathrm{I} 2$ months after the earthquake (BBC News Asia, 2012).

We interviewed people who were living in Kasai Temporary Housing in the city of Ishinomaki in Miyagi Prefecture. The air-conditioned containers measuring 30 square metres were of high quality, with two rooms, a kitchenette and a tiny bathroom, but they are cramped and people have to live in them four or more years.

An important issue is the extent and the complexity of land use changes. After the I933 Sanriku earthquake and tsunami, safe resettlement areas were designated in the government's post-tsunami recovery planning. Resettlement on higher ground reduced damage and casualties in $20 \mathrm{II}$ and demonstrates the importance of land use mitigation for tsunami-related disaster reduction (Imamura, 20I4). Research also suggests that, between I948 and 20I0, many people, for convenience or reason of ownership, returned to the original tsunami-prone sites along the Sanriku coast or began living in vulnerable lowlands, a move that contributed greatly to the losses (see Figure 5) (Murao and Isoyama, 20I2).

Japan has a centralised political structure in which the national government maintains close oversight over local government. Following the promulgation of the Omnibus

Figure 5. Residential returns to tsunami-prone sites in Hongo, Touni Village, Iwate Prefecture, 1948-2010
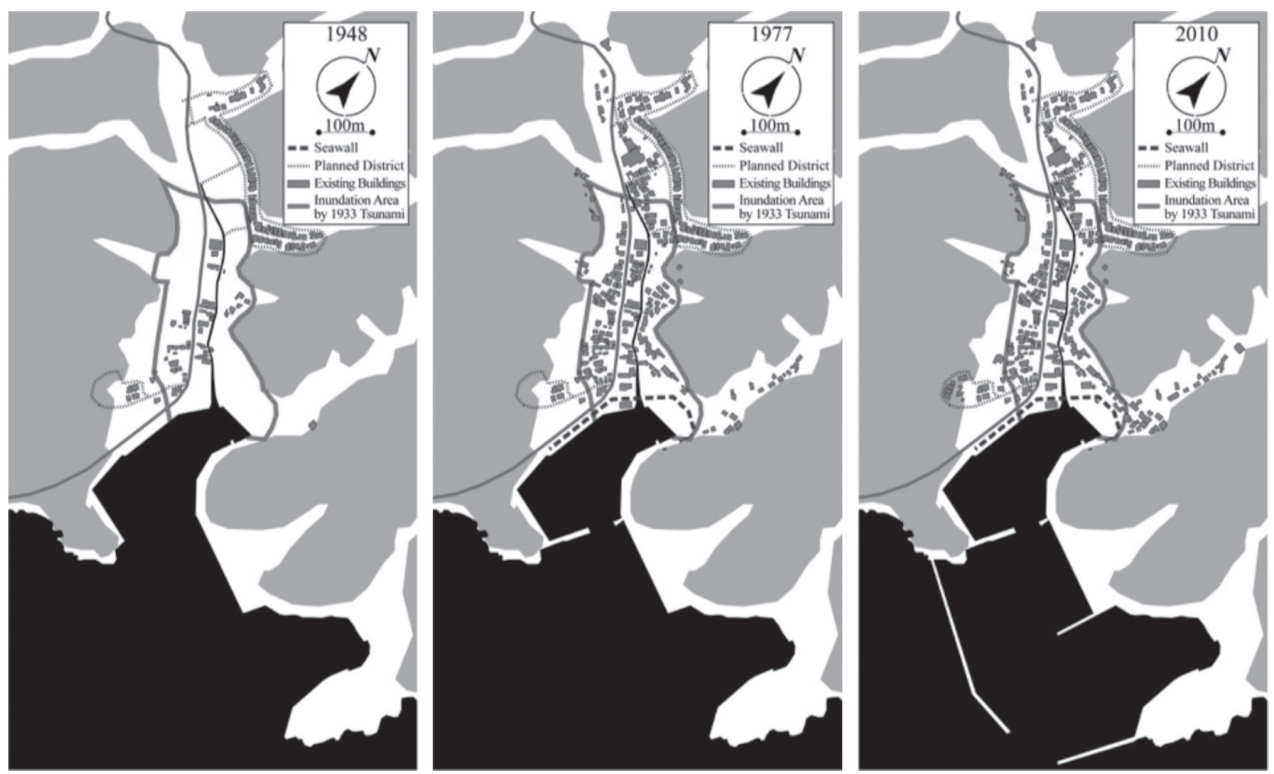

Source: Ono (2014). 
Decentralization Law in 2000, however, participation by residents in planning processes was encouraged and local governments began to devise various mechanisms for participation (Ohsugi, 20I0). Nevertheless, one of the most distinctive features of planning in Japan has been the virtual absence of civil society in the formation of city planning policy and practice (Sorensen, 2004).

The central government tried to speed up the process after the disaster of 20I I by providing guidelines, finance, human resources, and know-how, but leaving it to the municipal authorities to prepare detailed plans. Its top priorities are economic revival and safety. The economy is fairly strong in the Sendai plain, but the Rias coast was suffering economic and demographic shrinkage before the earthquake. The safety imperative has had huge implications for urban planning. No housing will be permitted in the hazard zone and buildings can be no more than five storeys with a shop or parking space on the ground floor. The two main protection strategies are relocating homes to safe places and providing multiple layers of protection. In the Sendai plain, where there are no natural hills, the government is building barriers and concentrating housing on raised platforms (see Figure 6). People who cannot afford to construct their own homes will be moved to higher density apartment blocks. This is contentious as many families want to move far inland away from the hazard zone.

Figure 6. The Iwanuma masterplan: six small settlements concentrated in a new urban centre raised behind three embankments

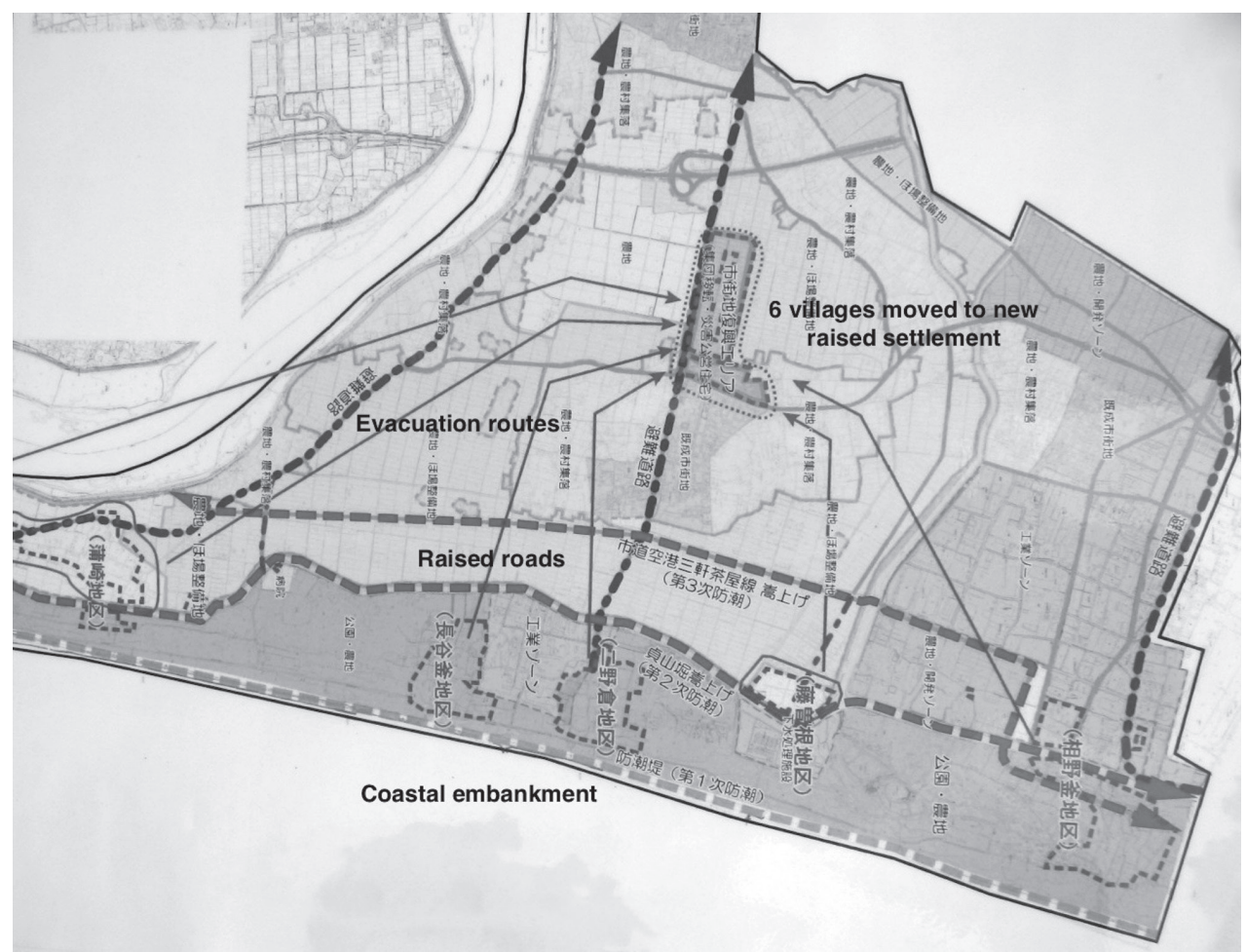

Source: authors' photograph of a public notice board, Iwanuma City, Miyagi Prefecture, 1 June 2013. 
Figure 6 shows a typical plan for the Sendai plain. There are three embankments: the coastal embankment and the two raised roads. All of the small settlements in the hazard zone will be concentrated in a new urban centre and new evacuation routes are being created. Along the Rias coast, residential areas in the hazard zone have been rezoned as non-residential and homes are being moved to higher ground. Designating new areas for housing, building embankments, and terracing slopes all takes time.

The International Recovery Platform pointed out that the problems of recovery are compounded by the shrinkage confronting most rural towns in Japan, where ageing and economic and population decline pose special planning challenges (Kawawaki et al., 20I3). The central government hoped that changes to land use (redefining housing areas in hazard zones as non-residential), improving transportation links, and promoting urban centre regeneration projects would have a positive impact on the prospects of these places, as well as making them more resilient to future disasters. Measures that would strengthen existing local businesses and city-centre shops, attract new industry, and encourage young people to move to the city might have been considered, but the lack of jobs has meant that many young people have left the area in search of work and better prospects. Up until mid-20I4, though, the focus was on relocating housing to higher ground and on constructing safety measures such as high levees and evacuation towers, rather than on strengthening the local economy and addressing economic and demographic decline.

There is a question about how much room for adaptation there is locally in the application of the central government's template for recovery. Japan is a compliant society and there may be more flexibility than local officials or residents realise. There seems, however, to have been no cost-benefit analysis of the huge investment. One of the biggest areas of controversy is the building of 400 kilometres of concrete seawall of up to nine metres high at a cost of nearly USD 8 billion, or USD 2,000 per metre (NHK, Japan Broadcasting Corporation, 2015).

By law, the authorities are obliged to solicit local public opinion; from the earliest stages, residents' views were sought during public meetings, surveys, and workshops, but this takes time and causes delay. Members of the younger generation, in their forties, are opposed to large embankments and tall seawalls, but they are not the decision-makers. Community groups and municipal authorities are dominated by elderly men who tend to be conservative and safety conscious.

The response of the majority along the Rias coast was that the government had already decided so they cannot do anything. Some even admire the massive infrastructure. Unfortunately, people continue to leave and the community may fragment because of the delay. Partly because of citizen opposition, the reconstruction of sea embankments, which suffered extensive damage, has been delayed considerably. Local governments in devastated areas cannot decide on the details of restoration plans, as discussions continue on whether or not to prohibit people from returning to coastal areas. At the time of the authors' fieldtrip, 26 months after the tsunami, reconstruction work had started on only 3 I per cent of the destroyed embankments (Daily Yomiuri Editorials, 2013). 
In Ishinomaki, a large port city east of Sendai in Miyagi Prefecture, there were plans to revitalise the city centre. The local community was involved in community workshops a year after the disaster, during which there were open discussions about the future of the place. The point of concern that caused the most delay was the plan for a river protection wall. Historically, the centre was located near the river because of the transportation of rice, and many residents object to building a high wall. The debate centres on balancing protection and historic value. The government had proposed a 4.5 metre high levee and the citizen's committee of stakeholders was deliberating how to make the area attractive for visitors when the fieldtrip took place. There are plans for a riverfront development to attract visitors, including a fish market with a food court and a memorial to those who lost their lives.

At Shibitachi on the Rias coast a banner stretched across the village indicating the height of the proposed embankments. The base will cover much of the flat area of this small fishing village. There are 270 households of elderly 'recreational' fishermen and their homes will be relocated to higher ground. At Oya East, a beach community near Kesennuma, the community group organised by Miura Tomayukin suggested that the proposed nine metre high embankment be moved back. Initially the city was unhappy with the idea but changed its mind after receiving a petition. The proposed municipal plan is now for a lower embankment farther back, but this needs the cooperation of the Department of Agriculture and Fisheries, the National Forestry Department, the Prefecture's Civil Engineering Department, Japan Railways, and the National Highways Agency ${ }^{2}$. The overlapping responsibility of five different agencies makes decision making difficult and causes delay.

In Kesennuma City, Akihiko Sugawara, owner of the Sugawara Sake Brewery, Vice-President of the Chamber of Commerce, and a member of the Strategy Committee of Municipal Government, said that a citizens' committee opposes the planned five metre embankment as it will change the character of the picturesque seaside town. Most residents were evacuated safely, but they are used to living by the sea with all its attendant dangers. Committee members are concerned that a delay in reconstruction will stall economic recovery. The majority of residents are against the proposed seawall and hence the deadline was pushed back six months to October 20I3. Even Japan's First Lady, Akie Abe, said in an interview with Mainichi Shimbun Weekly News (20I4) that she had been to Kamaishi recently and that she opposed the massive seawall construction project. More recently, in an article in The Japan Times (Daimon, 20I6), she stated that 'it's misleading to call the construction "restoration work". Local governments are not rebuilding walls that were destroyed by the quake and tsunami ... they are replacing 5-meter seawalls with barriers that, in some cases, are twice as high as their predecessors'.

Local government has considerable problems with consultation, which is timeconsuming. It is not easy to convince communities to relocate yet people want to be safe. The fundamental problem is that the authorities do not really know the likely size of the population in each place needing reconstruction. Local governments want to consolidate communities to make it more efficient and economical to deliver 
services, since many of these places were in decline before the tsunami. If the municipal authorities have to provide facilities and services for each community, no matter how small, the cost will be enormous. ${ }^{3}$

Overall, recovery in Japan has been slowed by deliberation and the safety imperative of building back better. But the picture is complex. Seawalls and relocation are appropriate in some places, such as in Iwanuma and Natori, Sendai, and plans here have proceeded relatively quickly. In other places, such as in villages and towns along the Rias coast from Ishinomaki to Kamaishi, expensive seawalls will destroy beaches and harbours and people are resistant to being relocated inland or herded into larger centres. This deliberation has undoubtedly slowed things down, but the outcomes may be better and more acceptable in the long run.

\section{Turkey}

The magnitude 7.2 (Mw) Van earthquake (USGS, 2OI I) occurred at I3:4I local time on 23 October 20 I I and was felt throughout eastern Turkey and adjacent countries. The epicentre was I6 kilometres north-northeast of Van near the town of Erciş (CEDIM, 20II; EERI, 20I2). Van and Erciş had official populations of 526,725 and I59,450 respectively at the time of the disaster, although the actual number of inhabitants may have been as many as one million people in total. The earthquake caused 604 fatalities and 4,I52 casualties (AFAD, 20I2) as well as significant damage in Van and Erciş and many villages. An aftershock of magnitude 5.6 (Mw) on 9 November claimed another 40 lives and produced further damage (EERI, 20I2). There was massive damage to buildings owing to poor masonry construction and the inadequate application of building codes (Turan, 2OI2). A total of 28,5 2 buildings suffered heavy damage in the initial earthquake, including I8,424 dwelling units. This figure rose to more than 35,000 following the aftershock (Erdik et al., 20I2). In total, 6o per cent of housing in the Van region was damaged.

As in many other parts of Turkey, most of the existing buildings had not been properly inspected during design and construction. Although engineered buildings are generally designed by qualified engineers, in situ construction is typically overseen by an uneducated foreman and non-engineered buildings are all designed and constructed by uneducated workers (Tapan et al., 2013).

Van is one of the most backward areas of the country. More than one-half of the population (6I per cent) has education below high school and only Io per cent have a university education (Ikizer, 20I4). People's perception of risk in Turkey is unreliable. A 2008 survey of more than 800 residents in two districts of southwest Istanbul, Avcılar and Bakırköy, which were badly affected by the magnitude Mw 6.7 Kocaeli earthquake in August 1999, revealed that awareness of potential danger is strongly correlated with educational background (Eraybar, Okazaki, and Ilki, 2oro). The majority of respondents (greater than 60 per cent) thought that a major earthquake would occur in the area within 50 years and 45 per cent thought that it would occur within Io years. Yet, despite the apparent danger, the majority ( 59 per cent) planned 
to remain in their current house for more than Io years. Most (8o per cent) believed that their house was strong enough to survive such an event and only 8 per cent had considered retrofitting their home.

Van is also one of poorest regions of Turkey and total economic damage is estimated at USD I billion while insured losses are believed to be in the region of USD 20-IOO million (CEDIM, 2OII). Although there was much less damage than in Japan, the economic life of Van was destroyed by the earthquake, leaving most people without jobs.

At one time nearly 300,000 people were being housed in temporary shelters in Van and Erciş and perhaps as many as 200,000 left the area and went to stay with relatives or in accommodation organised by the government in other cities. As in Japan, lessons were learnt after an earlier event (the Kocaeli earthquake of I999). Shelter was provided quickly, and people did not have to stay in containers as long as they did in Japan. The 2I square metre container houses, smaller than the Japanese versions, but housing much bigger families, comprised two rooms and a kitchen, bath, and toilet. We visited Van exactly one year after the 20I I earthquake and all of the camps were full (see Figure 7). They were well policed and contained shops, schools, and play facilities. When we returned six months later they were nearly all empty.

Major progress had been made in rehousing people and boosting the economy by one year after the earthquake. Some 30,000 people had been rehoused in the city and some 70,000 people were moving to the new suburbs. ${ }^{4}$ People are moving to houses built by TOKI, the government's housing agency, on five sites around Van (see Figure 7).

TOKI has been active in the construction of social housing since the I980s and currently functions as both a regulator and as a provider of social housing. Initially

Figure 7. Temporary camp and new housing in Van, Turkey
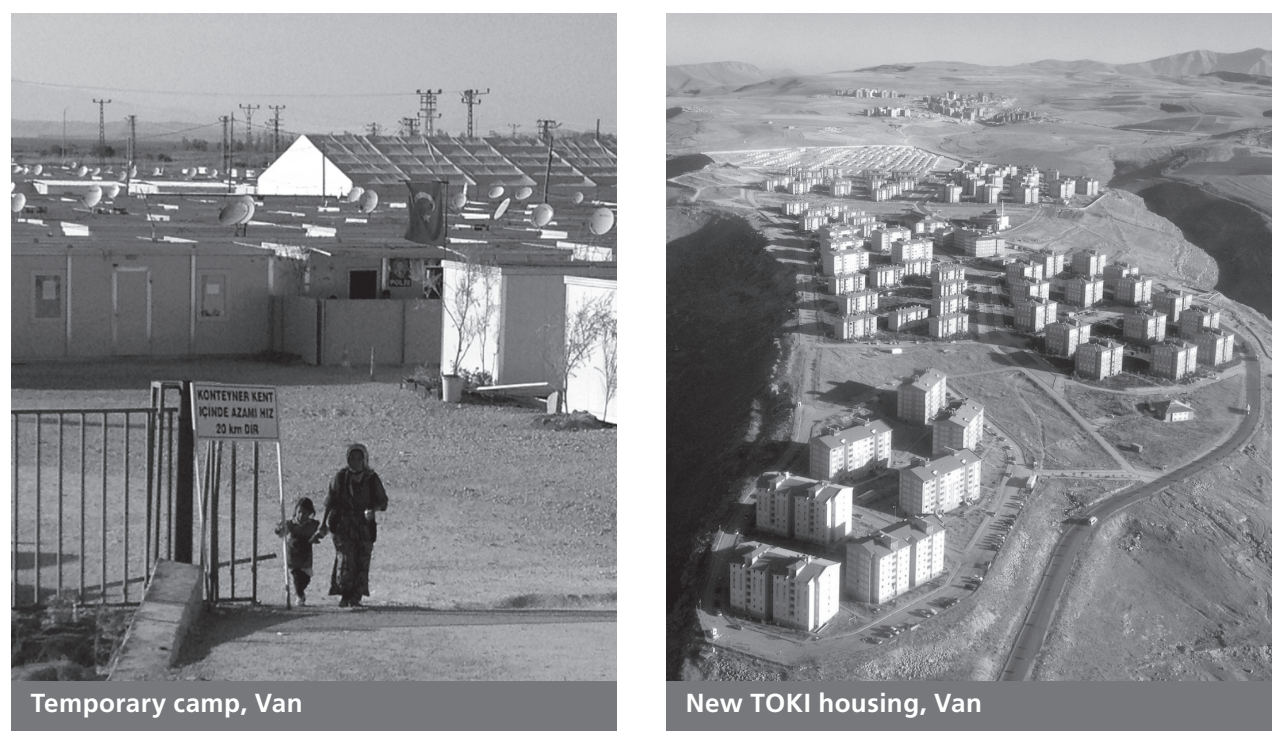

Source: authors. 
the agency supplied financial support for social housing, but it has been the direct provider of social housing since 2003 . TOKI, though, has little understanding of or expertise in urban planning or new settlement creation.

The political stability of the past decade has yielded economic development and there has been massive state investment in the region in roads, infrastructure, and new settlements (Üngör and Kalafatc1lar, 20I4). However, the economic bounce from construction is only temporary and long-term recovery is less certain. ${ }^{5}$

Although emergency response and relief by AFAD was well organised and effective, in other ways Turkey was ill-prepared for this earthquake. Disaster crisis management is highly organised in the country, but the focus was on the disaster response and early recovery phases; not enough attention was paid to mitigation or long-term recovery (Caymaza, Akyonb, and Erenelc, 20I3). As the Mayor of Erciş, Barboros Baran, pointed out: 'It is difficult to recover quickly, the earthquake left us with a big economic problem, but slowly the city is returning to normal'. ${ }^{6}$ Schools and shops have reopened; there is traffic in the streets; and there is a great deal of construction. More fortunate families have a member who is back at work, as a schoolteacher or taxi driver, for instance. It will be a long time before most people are fully recovered; for some this may never happen (Beam, 2012).

The Government of Turkey introduced compulsory earthquake insurance in 200I and threatened to cut off electricity and water if people had no insurance. The law was enforced for only one year, though; people now buy insurance only when they sell the house. In Van, insurance penetration, 9 per cent in 20I0, one year before the earthquake, is much lower than it is in Ankara (42 per cent) or Istanbul ( 36 per cent) (TCIP, 2OII). People were treated to the same level of government compensation whether or not they had insurance. The decision was political, as the situation in Kurdish-dominated Van was fragile after the disaster: the government used the extraordinary situation to improve its popularity in light of the upcoming elections. The simple fact is that people who were not insured should not have been rehoused in the same way as those who were, but this would have been politically unacceptable to the government.

Since the start of the twenty-first century, Turkish cities have undergone largescale change through a process referred to as urban transformation (Elicin, 20I4), involving the demolition of low-income inner-city settlements. One of the justifications for the policy is to protect people from earthquakes (Saraๆoğlu and DemirtaşMilz, 20I4). The Urban Transformation Law of 2012 aims to increase the safety of existing housing stock by defining earthquake hazard zones and obliging people living in them to get professional help to analyse the earthquake risk of their building. The law, which entered into force on I6 May 2012, is new as of this writing and is in the process of being applied. ${ }^{7}$

Changes in local government have also occurred over the same period. Unlike in Chile and Japan, however, local democracy in Turkey does not really entail power distribution, political representation, and participation. Municipal Law No. I580 of I930 sidestepped the democratic development of Turkish local government by making 
it dependent on central resources and decisions. Although municipal government has been transformed since 2000 , control of municipal functions and resources by central government is being switched to local mayors (Bayraktar, 2007).

We visited a number of these new estates in the Van area. They are well built and most have a central play area for children. Many new cars are parked outside and people are generally getting on with their lives. The housing is government subsidised; each house costs about USD 35,000 and is free of charge for the first two years, then subject to monthly interest-free payments of USD I6o over I8 years. One issue is that these apartments are typically Ioo square metres and the average family size is Io. ${ }^{8}$

AFAD defined the location for new housing based on geological considerations and land ownership and legal issues. Largely because of the intense imperative for speed this invariably meant government-owned land. TOKI then managed all aspects of the construction and built some I5,000 apartments in Van and 5,000 in Erciş in less than 2 months from the date of the earthquake. This rate of reconstruction is unprecedented. The reason it was so fast was that planning decisions were made by AFAD geologists on the basis of distance from a known fault and whether the land was government-owned. There was no public consultation of any kind.

AFAD engineers maintain that the impressive speed was due to taking the right decisions and, in the main, selecting good sites. This strategy of moving people to new peripheral settlements has meant that the city is expanding, particularly towards the south and east; planners have focused on new roads and connections to these subcentres. However, the new homes are isolated from the town centre and various experienced earthquake engineers are critical of scientific advice overriding logical urban planning criteria.

Despite talk of rebuilding a better Van, we did not see much sign of urban planning, either in the existing town centres or in the new TOKI housing estates. Neither AFAD nor TOKI engaged in any urban planning for the new settlements, and although they completed 20,000 new homes within one year of the disaster, these should have been planned better. ${ }^{9}$ When we visited the Ministry of Environment and Urban Planning team in Ankara responsible for Van, they were busy mapping existing use of land rather than planning how the city might be made 'more liveable'. It has been almost impossible for the urban planners to produce radical plans to improve the city centres of Van or Erciş because of landownership issues. It is complex and expensive to 'expropriate' private land in Turkey and owners do not want to give up land for street widening, parks, or any enhancement of the public realm. ${ }^{\text {Io }}$

One of the key post-disaster questions facing the authorities and building owners in Van, as elsewhere, is whether to repair or rebuild. The answer is influenced by a number of factors:

- the scientific and engineering assessments of ground conditions and the structural integrity of the building and its vulnerability to future hazards;

- the application of building codes and the rigour of the inspection process;

- whether the building is insured and for how much; 
- the relative cost of repairing and rebuilding;

- the possibility of developing the site by increasing the number of storeys or improving the planning or functionality of the building;

- the availability of funds, either in terms of capital or low interest loans; and

- multiple ownership or legal issues and the owners' personal preferences.

Approximately one-half of the damaged residential property in Van and Erciş will be repaired. A higher proportion of commercial property is likely to be repaired than rebuilt, because most owners will rebuild on the same site rather than moving and there is less financial support for commercial property. Yet, there are issues with the building inspection system. Notably, there are several layers of control and architects or construction managers need to get approval from several different institutions (Özden, 20I4). New legislation passed after the earthquake suggested that this system would be reviewed. But from what we saw, the system does not seem to be working. We inspected a seven-storey building in Erciş next to the District Governor's Palace where all of the columns had been sheared at the base. The owners have permission to shutter and repair the columns in situ. The District Governor told us that he did not know about the building next door, but said that building control was much better than it had been seven or eight years ago and that qualified engineers decided on repair or demolition.

\section{Chile}

The magnitude $8.8(\mathrm{Mw})$ Maule earthquake occurred at 03:34 on 27 February 2010 at a depth of 35 kilometres (USGS, 20I0). The event was centred 200 miles southwest of the capital of Chile, Santiago, with a rupture zone of 500-60o kilometres. It was the fifth most powerful earthquake since seismic records began in I99I and triggered a tsunami that caused severe damage to many coastal settlements (Lubkowski et al., 20IO). By most standards the Maule earthquake was a catastrophe for Chile and affected more than two million people. Chileans reported being surprised that they were not as ready for this event as they thought they were.

Most buildings performed as they had been designed, to protect life, but economic losses were huge, totalling approximately USD 30 billion or I7 per cent of gross domestic product (GDP) (Franco and Siembieda, 20Io). Despite the magnitude of the earthquake there were few major structural collapses and a relatively low death toll: 525, with another 25 missing. The standard of construction in Chile generally is good (Booth and Taylor, I988), and the majority of fatalities, as in Japan, were due to the tsunami rather than to the earthquake.

Several factors contributed to the low casualty rate and to rapid recovery, especially the robust building code and its comprehensive enforcement. In particular, Chile has a law that holds building owners accountable for losses in a new building for Io years. There were few fires after the earthquake, because the electricity grid was shut down immediately. In many areas, the emergency response was very effective and there was close local coordination between emergency managers and fire and 
police personnel, without a need for communication with the capital. Finally, the high level of awareness meant that most people evacuated in good time and were able to manage living in temporary accommodation.

Pablo Allard was appointed National Coordinator of Urban Reconstruction at the Ministry of Housing and Urban Development. ${ }^{I I}$ The slogan of the Plan de Reconstrucción (MINVU, 20IO) is: 'Our challenge: turn a catastrophe into an opportunity . . . for better cities, better life'. It highlights that 'the earthquake affected severely the second biggest urban area in the country-Grand Concepción-and partially devastated five cities with more than I00,000 inhabitants, 45 cities with over 5,000 inhabitants and more than 900 towns and villages on the coast or in rural areas'. In addition, it underlines that the state is unable to reconstruct everything or even control the process of recovery centrally from Santiago. It is the responsibility of each region, town council, and community to develop its own plans, with the support of the state. The Plan adds that, although the authorities in each locality face huge problems that they will want to address immediately, it is important that they have a longterm strategic vision and that they proceed methodically in dealing with important issues concerning cultural identity, the environment, and citizen engagement if opportunities to build back better are to be realised.

Almost immediately after the earthquake a group of Io architects/planners was seconded from the two main universities in Concepción, Universidad Bio-Bio and Universidad Católica de Chile, to the regional government to form a master planning team to assist the affected local authorities. Of the 36 coastal settlements in the region, I8 suffered severe damage; the team decided to concentrate its efforts on these locations. They divided into three groups: Costa Norte, led by Ivan Cartes; Costa Centro, led by Waldo Martinez; and Costa Sur, led by Carolina Arriagada. ${ }^{\mathrm{I}}$ These academics worked closely both with the planners in the various municipal authorities and with local residents and business people in the affected settlements to develop a masterplan, Plan de Reconstrucción del Borde Costero, for each hamlet. Other outputs of this process were zone maps, depicting recommended areas for amenities, commerce, housing, industry, and infrastructure. Three levels of housing risk were defined based on the wave level (Level I: no risk; Level 2: low risk-houses with a reinforced concrete ground floor; and Level 3: high risk-tsunami-resistant housing with an unoccupied ground floor).

One-fifth of the population in Maule was made homeless by the earthquake and along the coastal margin a concrete toilet block often is all that is left of most homes. Displaced persons were given two options: (i) to stay on their property; or (ii) to move to an Aldea, or temporary housing village. In both instances, displaced persons were housed in Media Aguas, or temporary timber housing. Grants for tools and supplies were distributed to those working on repairing their homes (Hinrichs et al., 20I I). Temporary housing was constructed from local timber and some families incorporated the shelter into their rebuilt homes. These homes are one-room, I8 square metre timber chalets, smaller than either the Japanese or Turkish equivalents, and the camps comprised 250-500 units plus sanitary blocks. However, many of the approximately 
80,000 displaced families were still living in temporary camps like the ones we visited on the hillside above Dichato and Talcahuano I8 months after the disaster.

The plan is to build 70,000 dwellings and the goal was to have everyone back in permanent housing by the end of 2012. Allard is quoted as saying: 'This is one of the most complex reconstruction efforts anyone has ever undertaken . . Reconstruction means not only rebuilding what was there before, but rebuilding it better, much better ... We can't just build short-term ghettoes. We have to rebuild these cities to mitigate the [future] risk and exposure to earthquake and tsunami hazards' (Padgett, 20II). There was extensive interaction with residents and local businesses through focus groups and face-to-face meetings (González Muzzio, 2012). As members of resident and community groups had problems understanding maps, images and sketches were used to share ideas (see Figure 8).

The recovery manuals that the reconstruction team consulted (FEMA, 2008a, $2008 \mathrm{~b}, 2008 \mathrm{c}$ ) stressed that, after the immediate relief effort, it was important to reinstate livelihoods as quickly as possible, both to take people's minds off the tragedy and to make them independent of state support. Consequently, the main focus of the master planning team was to get business and commerce up and running. In addition, the team designed and built temporary restaurants set back from the beach and designated land for a park and the planting of trees.

Figure 8. Community engagement after the Maule earthquake: Residents' Association meeting in Tubul

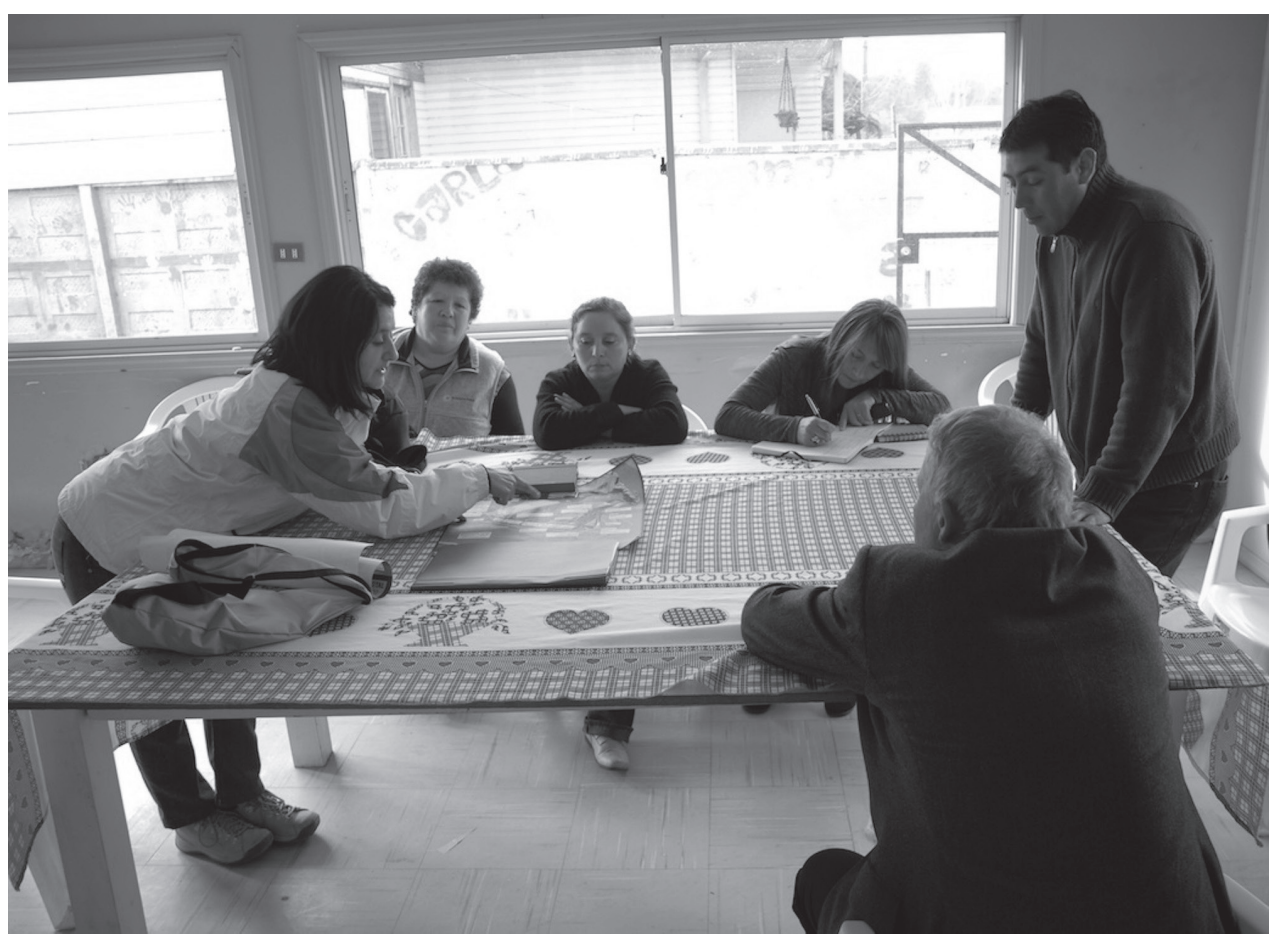

Source: authors. 
Figure 9. Tubul masterplan (Plan Maestro Tubul, 2010)

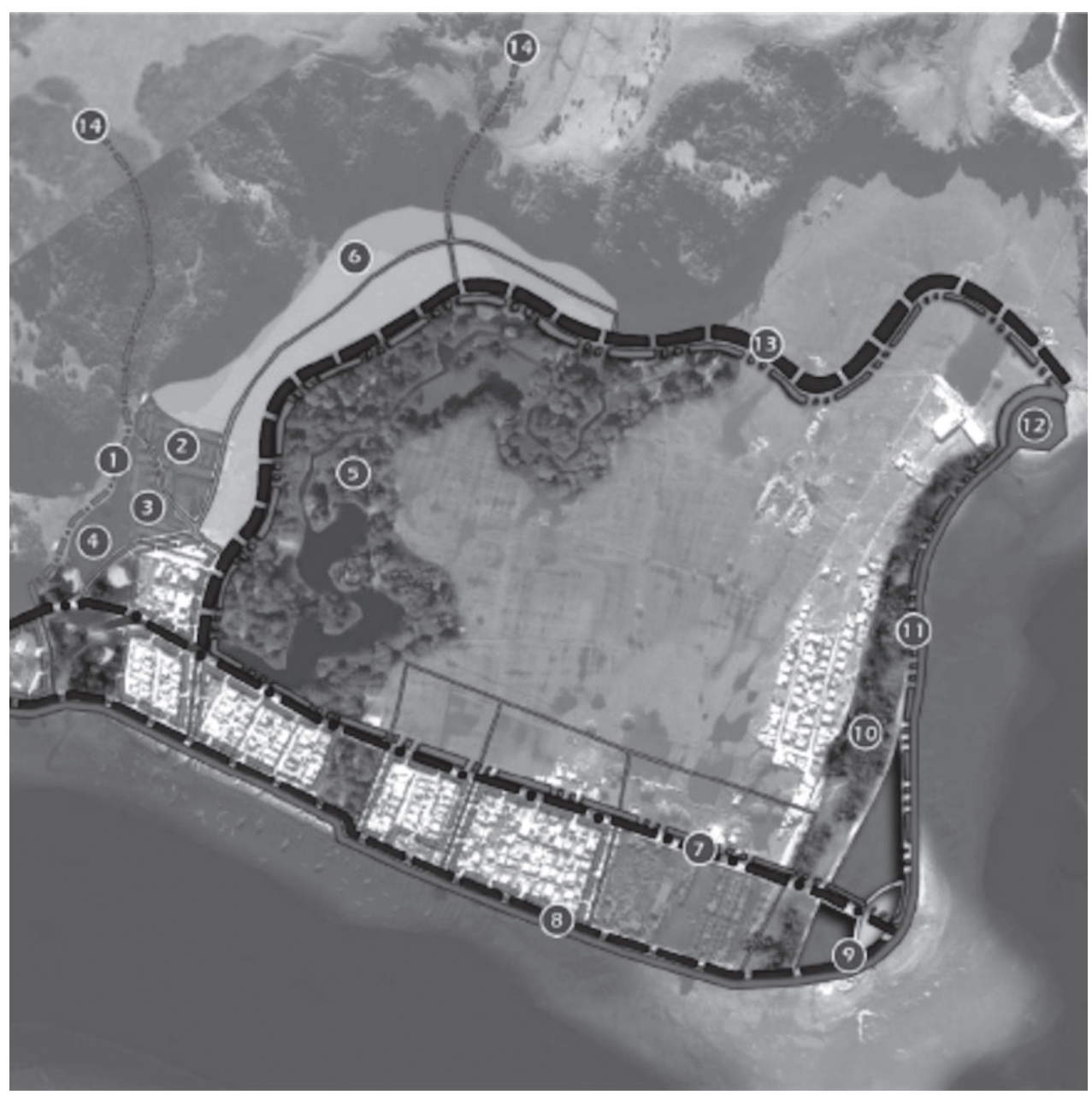

Source: authors.

The main components of the Dichato and Tubul masterplans are moving buildings back from the beach, planting trees, and canalising the river (see Figure 9). The sea defences proposed involve a much lower sea wall than in Japan, a setback of 50-80 metres for buildings, and a 20-30 metre band of trees. Carolina Arriagada, the leader of the Costa Sur group, explained that, in Tubul, the coastal strip where people had been living was unsafe and the plan was to move the majority of homes to higher ground at the other end of the village, necessitating the purchase of land from the latifundista landowner.

Homes being built on the site of the existing village are tsunami-resistant. The government expropriated existing homes and paid people the commercial value for the house and improvements, independent of the subsidy for the new housing. The new homes are I 4 square metres, slightly smaller than the existing houses. Residents were closely involved in planning the move and in decisions about the design of the 
homes - interestingly, it was the Great East Japan Earthquake of 20 I I that helped to convince the undecided in Chile about moving. However, the Plan Maestro Tubul took longer than predicted because of the lack of good information, especially mapped cadastral data on who lived where.

Our impression, from talking to people in the various coastal settlements we visited, was that the need to balance speed and deliberation had been managed with some skill (Platt, 2OI2). There was intense pressure from residents to rebuild homes, to restore facilities, and to get the economy moving and there was a desire on the part of the authorities to develop new urban plans that would improve these communities and make them safer. The master planning team produced the plans and got the funding within I2 months. Most impressively, they were able to involve residents and business people in the planning process and to keep them informed via regular fortnightly visits and walkabouts in the community.

\section{Conclusion}

In Japan, the nation was traumatised by the unanticipated scale of the disaster. It is a matter of national pride to rebuild shattered communities and to make them safe 'at any cost'. This safety imperative means that ways of life and people's relationship to the sea will have to change; this is a painful reality and causes dissent. By law, the authorities have to consult people and it is in the nature of Japanese society to try to reach consensus rationally. All of this takes time, undermining the possibility of recovery in places that were already in demographic and economic decline.

In Turkey, the imperative was speed, particularly to provide temporary accommodation and then to rehouse people in permanent housing. The new TOKI housing will be much more earthquake-proof than previous homes and new hospitals, schools, and government buildings will be built to code. All buildings must be inspected before they can be repaired and, in theory, dangerous buildings that cannot be repaired will be demolished, although we witnessed many examples of inadequate and dangerous reconstruction. Van will be much safer, but little urban design or planning underpins the fast-paced reconstruction.

Chile achieved a better balance between speed and deliberation. The central government recognised that it would be unable to reconstruct everything or even control the process and national coordination was limited to defining the scale of the problem and allocating resources. Planning and implementation was the responsibility of regional government and specialist teams of experts. What distinguished recovery in Chile was community consultation and the desire to rebuild as quickly as possible from the bottom up but also to build back better.

\section{Land use change and safety}

There are essentially three choices regarding land use planning: (i) rebuild in the original place; (ii) move to a safer adjacent neighbourhood; or (iii) relocate to a new place. 
In addition, there is also the issue of whether to move whole communities collectively or whether individuals should make their own arrangements (Iuchi, 20I5). This decision depends largely on the degree of damage, the willingness of the inhabitants to move, the difficulty of mitigating future risk, and the economic implications of the move (Ye, I996).

In Japan, the policy was to define a hazard zone and to move people up and away. In the Sendai plain, this involved moving people out of detached houses and into apartment blocks on raised platforms some distance from the coast. On the Rias coast, homes were moved to higher ground on new terraces. In Turkey, between onethird and one-half of displaced persons were rehoused in new apartment blocks sited on land five to six kilometres from the city. The rest of the population plus new migrants to the city were housed on redeveloped demolition sites or in repaired houses. In Chile, commercial and industrial facilities were moved back from the coast to behind a new promenade and a treed margin that will protect against storm surge and break the force of a tsunami. Housing in the hazard zone will be tsunami-proof.

\section{Economic recovery}

Economic recovery is quite likely the most serious issue facing most communities in a post-disaster period, and almost certainly the central issue confronting national authorities in every major disaster. Bolton (I996) points out that a major disaster spawns an urgency to decide many things at once.

In Japan, much of the area affected by the disaster was in economic decline. The country has been in severe recession for decades and has a low birth rate and an aging population. The tsunami aggravated these problems. The government is trying to support industry and commerce through the provision of financial support and by improving transport links, but there is only so much it can do in the face of economic forces. In Turkey, there has been major investment in new highways and infrastructure. This has produced a mini boom in construction but unemployment is high, and although some are getting rich through reconstruction, the majority of the population is struggling to make ends meet. This is a border area with Iran and much of the economy is based on trade, both legal and illicit. It is unclear whether this area will prosper or fail in the longer term. In Chile, the government assessed damages and losses at USD 30 billion, and estimates total public spending for reconstruction at USD I2 billion. It will probably fund this spending through moderate tax increases, drawing on reserves, budget reallocations, the sale of assets, and, most significantly, concessionary schemes with the private sector.

\section{Planning system}

A large number of authorities and organisations are involved in different aspects of recovery. There is a range of pre-existing and special earthquake-related plans. In many countries it is unclear which agency, department, or organisation is responsible 
for planning post-disaster recovery. There is a pressing need to coordinate decisionmaking, land availability, the reconstruction programme, and service provision, but often there is tension between local, regional, and national authorities.

Japan faces a major bureaucratic challenge in that many different agencies need to coordinate decision-making. Major planning changes also require extensive public consultation and community agreement. This means that planning is slow and cumbersome, since plans are considered and evaluated carefully. In Turkey, in contrast, most of the important decisions are taken by officials in the capital, Ankara, without much reference to local stakeholders and with little or no public consultation. Hence, decision-making is extremely rapid, but plans are much less likely to meet local people's aspirations, and opportunities to improve urban planning have been missed. In Chile, the really distinctive aspect of the recovery process was the quality of participation: the community was involved in decision-making and was kept informed of progress. The architects heading the three groups visited their areas regularly, at least once a fortnight, meeting residents and business people and just walking the streets. The first author accompanied two of them on various trips to the affected area and attended resident association meetings and ad hoc meetings with restaurant owners and shopkeepers, witnessing the quality of this consultation in action.

\section{Insurance and government subsidy}

Insurance can be a powerful ex-ante strategy in an earthquake risk mitigation framework. Its primordial objective is to provide monetary compensation for damaged assets or lost income, but also it can help to achieve other important goals for society, such as the establishment of safer building practices, the dissemination of risk information, and the promotion of financial responsibility (Franco, 2OI4). Carpenter (2OI4) estimates that 70 per cent of global economic losses due to natural catastrophes between I980 and 2013 were uninsured. Moreover, as risk exposure grows at a faster pace than insurance, the gap keeps widening.

\section{Political issues}

Davis (2006) points out that all aspects of disaster management, including longer-term recovery, occur within political contexts, that disasters place immense demands on government officials, and that the public, especially affected persons, has high expectations of leaders and public officials. However, the brevity or superficiality of media coverage tends to underrepresent the challenges faced by governments.

The Government of Japan has been under intense pressure, aggravated by its mishandling of the accident at the Fukushima Nuclear Power Plant in March 20II, to clean up and repair the damage and to make places safe. In a polite and restrained way there has been intense debate on the way forward, which has caused delays but may prove beneficial in the long run. In Turkey, there was a political imperative, because of Kurdish separatist unrest, to react quickly and decisively. The government had 
Figure 10. Population pyramids

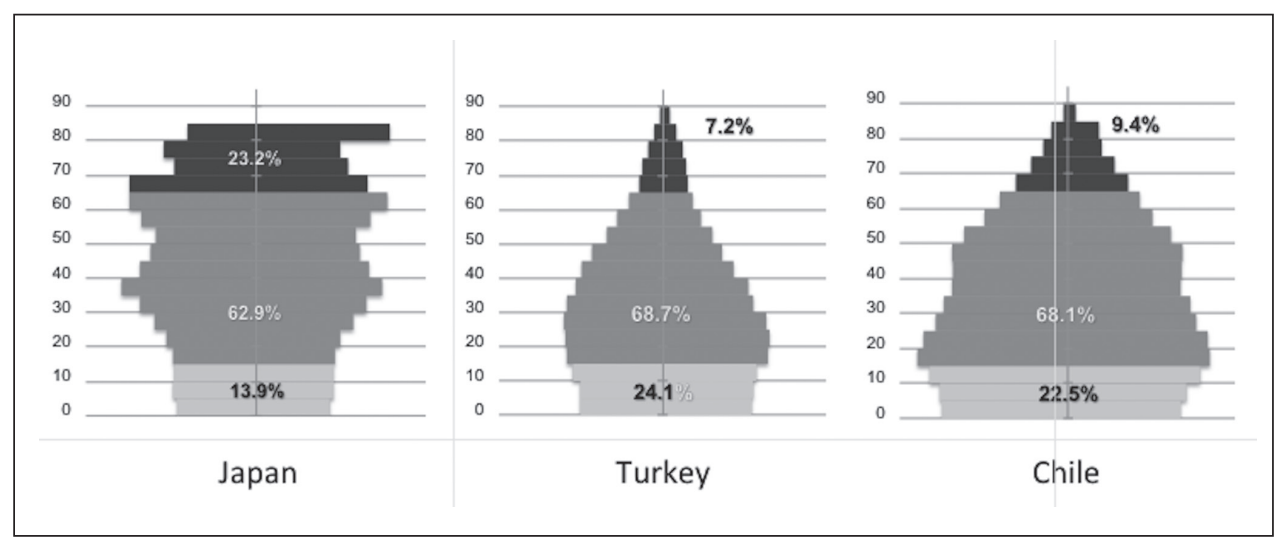

Source: authors' creation based on information from the US Census Bureau, International Data Base, 2010, http://www.census.gov/data/developers/data-sets/international-database.html (last accessed on 25 October 2016).

immense powers to act without recourse to the same level of public scrutiny and local debate as in Japan. In Chile, all those involved in reconstruction had a personal commitment to involve local people in decision-making and to keep them informed about progress.

This paper is not comparing like with like, of course. There are major differences in the cultures and economies of the three countries under review and the events were quite different in scale.

\section{Demographics}

In Japan, the key issues are an aging population and economic decline. Tohoku was already suffering shrinkage before the tsunami. It is now predicted that the population will decrease by one-third in the next 50 years, leaving only two in five people economically active. In contrast, Turkey has a young population and is growing both demographically and economically. The population of Van is predicted to rise from approximately 360,000 to one million in the next $20-30$ years. Chile is somewhere between the two (see Figure Io).

\section{Economics}

Figure II shows rebuild cost in comparison to GDP. The scale of recovery in Japan is much larger both absolutely and relative to the size of the national economy. The boxes also illustrate how devastating earthquakes are when accompanied by a tsunami. The Government of Japan has allocated USD 25 trillion for the first five years of recovery, largely financed by the sale of reserves, although no cost-benefit analysis has been performed as the priority is to get the country back on its feet. This shows the size of the economy relative to the size of the population, and one can see immediately how wealthy Japan is per capita as compared to Chile and Turkey. 
Figure 11. Scale of the disaster and the cost of recovery relative to gross national product (GNP) and population

\section{Economics}

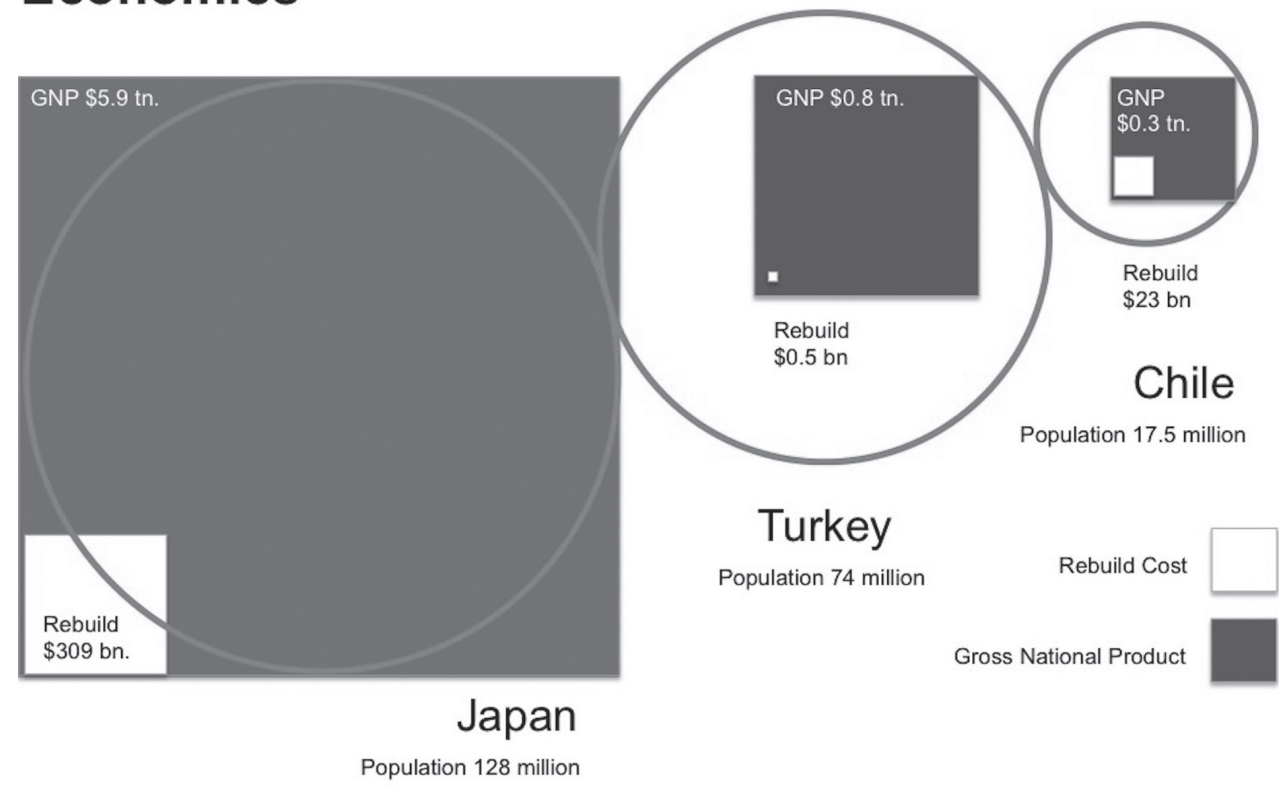

Sources: authors' creation based on information from OECD (2016) (for GNP) and from Ridgwell (2011), CEDIM (2011), and Fermandois (2011) (for reconstruction costs for Japan, Turkey, and Chile, respectively).

\section{Balancing speed and deliberation}

One has to balance speed and deliberation during any post-disaster recovery process. In an ideal world recovery would be both fast and deliberate and local communities would be involved in strategic decision-making. In sum, recovery in Japan might be characterised as deliberate but slow; in Turkey it might be depicted as all speed and little or no deliberation; and in Chile a balance was struck between the need for speed and a desire to build back better.

Despite the demographic and economic differences described above, the questions to ask are: 'Could Japan have been quicker?'; 'Would Turkey have recovered better if it had been more deliberate?'; and 'Will Chile actually be able to deliver what it promised?'. One can imagine that Japan might have moved more quickly if it had been better prepared psychologically and had managed public engagement better, and Turkey might have been more deliberate if urban planners had more influence. Only Chile, of the various places that have suffered recent disasters, has managed this balance successfully. Residents and local businesses in Chile wanted speed-they wanted to get back into their homes and to restore their businesses and livelihoods as quickly as possible. The national government, and the planning teams appointed by the BioBio regional government, wanted deliberation - they wanted to make homes, businesses, and critical services and infrastructure along the Maule coast more resilient to a future tsunami. Ultimately, each party got a reasonable amount of what it wanted. 
Comerio (2013) analysed housing recovery after the Maule earthquake of 20 IO. The disaster damaged or destroyed some 370,000 housing units (approximately Io per cent of the housing in six regions). Yet, within six months, the Ministry of Housing and Urban Development had published a plan to repair or rebuild, with governmental assistance, 220,000 low- and middle-income housing units within four years. In October 2012, at the midpoint of the programme, 54 per cent were complete and occupied and a further 30 per cent were under construction.

Several factors contributed to the success of Chile: strong leadership at the national and local level; the utilisation of existing initiatives and institutions; the flexibility to adapt programmes over time; a strong technical staff; a robust economy; and political will. Comerio (2OI3) concluded that countries can learn from each other and attempt to find the 'sweet spot' that results in the best of government management (in terms of expediency and flexibility) and incorporates opportunities for citizens to take some control of their own recovery, with regard to housing choice and participation in planning on the community's future. In this, she says, Chile's performance stands out.

What lessons can one draw from this admittedly brief analysis, and specifically, how might it be possible to secure both speed and deliberation in disaster recovery? The following three points are hypothetical, but it may be possible to apply them to other places:

- the national government needs to assess swiftly the loss, pass new legislation, and find the money;

- a special team needs to be seconded to plan recovery and be given a clear remit to balance speed and deliberation; and

- citizens should be consulted and kept informed of plans.

A fundamental piece of advice to countries with known major hazards is to rehearse and to make key decisions in advance. These 'meta decisions' establish a framework for subsequent decision-making and save time by eliminating whole areas of indecision. They include:

- Authority: who is in charge of disaster recovery (the existing authorities (line ministries and local government) or a special dedicated body)?

- Governance: to what extent is power centralised or delegated to local authorities? Are communities involved in setting the agenda and in decision-making?

- Planning: should homes and activities remain in situ or should they be relocated? Should any built-up land be abandoned and what new land should be brought into use?

- Construction: should buildings be repaired or rebuilt? The decision will depend on building code enforcement, insurance coverage, and the relative cost.

- Resources: where is the money coming from? Should people themselves or the government build new homes? 


\section{Correspondence}

Dr Stephen Platt, Director, Cambridge Architectural Research Limited, 25 Gwydir Street, Cambridge, CBI 2LG, United Kingdom. Telephone: +44 (O) I223 460475; fax: +44 (0)I223 464I42; e-mail: steve.platt@carltd.com

\section{Endnotes}

I The first named author of the paper originally trained as an anthropologist.

2 Personal communication with Miura Tomayukin, Community Worker, Mika Oya District, Kesennuma, Japan, 5 June 2013.

3 Personal communication with Sanjaya Bhatia, Head of the UNISDR (United Nations Office for Disaster Risk Reduction) Office for Northeast Asia, Kobe, Japan, 7 June 2013.

4 Personal communication with Altay Usly, Deputy Governor of Van, Governor's Palace, Van, Turkey, 26 September 2012.

5 Personal communication with Polat Gülken, Chair, Civil Engineering, Çankaya University, Ankara, Turkey, I October 2012

6 Personal communication with Barboros Baran, Mayor of Erciş, Governor's Palace, Erciş, Turkey, 25 September 2012.

7 Personal communication with Necmettin Şahin, Director, Disaster Management Centre, AFAD, Izmir, Turkey, 20 September 2012.

8 Personal communication with Nuray Karanci, Professor, Department of Clinical Psychology, Middle East Technical University, Ankara, Turkey, 2 October 2012.

9 Personal communication with Altay Erdugay, Professor, Earthquake Research Institute, Gazi University, and former President of TOKI, Ankara, Turkey, 3 October 2012.

1o Personal communication with Funda Torman, General Manager, Urban Planning Department, Ministry of Environment and Urban Affairs, Ankara, Turkey, I October 2012.

II Personal communication with Pablo Allard, Dean of Architecture, Universidad de Desarrollo, and National Coordinator of Urban Reconstruction, Ministry of Housing and Urban Development, Santiago, Chile, i6 September 20 I.

I2 Personal communication with Ivan Cartes Siade, formerly Dean Faculty of Arquitectura, Construcción y Diseño, Universidad Bio-Bio, Concepción, Chile, i2 September 20 I I.

\section{References}

AFAD (Disaster and Emergency Management Presidency) (20I2) 'Disaster report: Van earthquake'. https://www.afad.gov.tr/en/2603/Van-Earthquake (last accessed on 26 October 20I6).

Alexander, D. (2013) 'Planning for post-disaster reconstruction'. http://www.grif.umontreal.ca/ pages/papers2004/Paper\%20-\%20Alexander\%20D.pdf (last accessed on 26 October 2016).

Bayraktar, S.U. (2007) Turkish municipalities: reconsidering local democracy beyond administrative autonomy'. European Journal of Turkish Studies. http://ejts.revues.org/IIO3 (last accessed on 26 October 20I6).

BBC News Asia (2012) 'Japan quake: loss and recovery in numbers'. I I March. http://www.bbc.co.uk/ news/world-asia-I7219008 (last accessed 20 November 20I6).

Beam, A. (20I2) 'Turkey's slow recovery six months after the Van earthquake'. 2I April. http://www. mountararattrek.com/van_earthquake_20I2.htm (last accessed on 26 October 20I6). 
Bolton, P.A. (I996) 'The integration of housing recovery into reconstruction planning'. In F.Y. Cheng and Y.Y. Wang (eds.) Post-earthquake Rehabilitation and Reconstruction. Pergamon Press, Oxford. pp. $163-178$.

Booth, E. and C.A. Taylor (I988) The Chilean Earthquake of 3 March 1985: A Field Report by EEFIT. Bristol University, Bristol.

Brown, D., S. Platt, and J. Bevington (2010) Disaster Recovery Indicators: Guidelines for Monitoring and Evaluation. Cambridge University Centre for Risk in the Built Environment, University of Cambridge, Cambridge.

Carpenter, G. (20I4) 'Gap between economic and insured losses'. 20 January. http://www.gccapitalideas. com/2OI4/OI/2O/chart-gap-between-economic-and-insured-losses/ (last accessed on 8 November 20I6).

Caymaza, E., V.F. Akyonb, and F. Erenelc (2013) 'A model proposal for efficient disaster management: the Turkish sample'. Procedia - Social and Behavioral Sciences. 99 (6 November). pp. 609-6I8.

CEDIM (Center for Disaster Management and Risk Reduction Technology) (20II) Comparing the current impact of the Van earthquake to past earthquakes in eastern Turkey. http://earthquakereport.com/2OI I/II/o3/comparing-the-current-impact-of-the-van-earthquake-to-past-earthquakesin-eastern-turkey/ (last accessed on 26 October 20I6).

Comerio, M.C. (I998) Disaster Hits Home: New Policy for Urban Housing Recovery. University of California Press, Berkeley, CA.

Comerio, M.C. (2013) Housing Recovery in Chile: A Qualitative Mid-program Review. PEER Report 2013/or. Pacific Earthquake Engineering Research Center, University of California, Berkeley, CA.

Comfort, L.K. (2005) 'Risk, security, and disaster management'. Annual Review of Political Science. 8 (June). pp. $335-356$.

Daimon, S. (2016) 'Japan's first lady, Akie Abe, speaks her own mind'. I8 June. http://www.japan times.co.jp/news/20I6/06/I8/national/japans-first-lady-akie-abe-speaks-mind/ (last accessed on 20 November 20i6).

Daily Yomiuri Editorials (20I3) '2 years on, reality of recovery differs from official data. II March 20I3'. http://www.accessmylibrary.com/archive/434970-yomiuri-shimbundaily-yomiuri/march-2OI3page 4.html (last accessed on 2I August 20I4).

Davis, I. (2006) Learning from Disaster Recovery: Guidance for Decision Makers. International Recovery Platform, Kobe.

Edgington, D.W. (2010) Reconstructing Kobe: The Geography of Crisis and Opportunity. University of British Columbia Press, Vancouver, BC.

EERI (Earthquake Engineering Research Institute) (2012) The Mw 7.1 Erciş-Van, Turkey Earthquake of October 23, 2011. EERI Special Earthquake Report-April 20I2. https://www.eeri.org/wp-content/ uploads/Van_Turkey_eq-report.pdf (last accessed on 26 October 20I6).

Elicin, Y. (2OI4) 'Neoliberal transformation of the Turkish city through the Urban Transformation Act'. Habitat International. 4I (January). pp. I50-I55.

Eraybar, K., K. Okazaki, and A. Ilki (20IO) 'An exploratory study on the perception of seismic risk and mitigation in two districts of Istanbul'. Disasters. 34(I). pp. 7I-92.

Erdik, M., Y. Kamer, M. Demircioğlu, and K. Şeşetyan (20I2) '23 October 2or I Van (Turkey) earthquake'. Natural Hazards. 64(I). pp. 65I-665.

Fan, L. (2013) Disaster as Opportunity? Building Back Better in Aceh, Myanmar and Haiti. HPG Working Paper. November. Humanitarian Policy Group. Overseas Development Institute, London.

FEMA (Federal Emergency Management Agency) (2008a) Earthquake Publications for Community Planners and Public Policy Makers. CD-ROM. I June. http://www.fema.gov/library/viewRecord.do?id=3553 (last accessed on 26 October 20I6).

FEMA (2008b) 'Tsunamis'. https://www.ready.gov/tsunamis (last accessed on 8 November 20I6).

FEMA (2008c) 'Recovering from disaster'. https://www.ready.gov/recovering-disaster (last accessed on 8 November 20I6). 
Fermandois, A. (201 I) Chile and its earthquake - Preparedness, response and lessons'. March. http:// dels.nas.edu/resources/static-assets/materials-based-on-reports/presentations/Ambassador Fermandois.pdf (last accessed on 20 November 20I6).

Franco, G. (20I4) 'Earthquake mitigation strategies through insurance'. In M. Beer et al. (eds.) Encyclopedia of Earthquake Engineering. ISBN: 978-3-642-36197-5 (online). http://link.springer.com/ referencework/IO.I007/978-3-642-36197-5/page/3 (last accessed on 26 October 2016).

Franco, G. and W. Siembieda (20I0) 'Chile's 20I0 M8.8 earthquake and tsunami: initial observations on resilience'. Journal of Disaster Research. 5(5). pp. 577-590.

González Muzzio, C. (2012) 'Planning back better, urgent and important'. Paper presented to the 45th annual Salzburg Congress on Urban Planning and Development, Salzburg, Austria, 9-I2 May 20 I2. https://www.researchgate.net/profile/Claudia_Gonzalez-Muzzio/publications (last accessed on 26 October 20I6).

Graham, A. (1999) 'Sustainability and community resilience: the holy grail of hazards planning?'. Environmental Hazards. I(I). pp. I3-25.

Gunewadena, N. and M. Schuller (2008) Capitalizing on Catastrophe. Altamira Press, Lanham, MD.

Haas, J.E., R. Kates, and M.J. Bowden (eds.) (I977) Reconstruction following Disaster. MIT Press, Cambridge, MA.

Hinrichs, R., L. Jones, E.M. Stanley, and M. Kleiner (201 I) Report on the 2010 Chilean Earthquake and Tsunami Response. U.S. Geological Survey Open-File Report 20I I-IO53, version I.I. http://pubs.usgs. gov/of/20II/IO53/ (last accessed on 26 October 20I6).

Huang, Y., L. Zhou, and K. Wei (2014) '5.I2 Wenchuan earthquake recovery government policies and non-governmental organizations' participation'. Asia Pacific Journal of Social Work and Development. $2 \mathrm{I}(2) \cdot \mathrm{pp} .77-9 \mathrm{I}$.

Ikizer, G. (20I4) Factors Related to Psychological Resilience among Survivors of the Earthquakes in Van, Turkey. $\mathrm{PhD}$ thesis. Graduate School of Social Sciences, Middle East Technical University, Ankara.

Imamura, F. (20I4) HFA IRIDeS Review Report: Focusing on 2011 Great East Japan Earthquake. May. http://irides.tohoku.ac.jp/media/files/HFA_IRIDeS_Review_Report_Web.pdf (last accessed on 26 October 20I6).

Ingram, J.C., F. Guillermo, C. Rumbaitis-del Rio, and B. Khazai (2006) 'Post-disaster recovery dilemmas: challenges in balancing short-term and long-term needs for vulnerability reduction'. Environmental Science and Policy. 9(7-8). pp. 607-613.

Iuchi, K. (20I5) 'Planning resettlement after disasters'. Journal of the American Planning Association. 80 (4). pp. $4 \mathrm{I} 3-425$.

Kahneman, D. (2012) Thinking Fast, Thinking Slow. Penguin Books, London.

Kates, R.W. and D. Pijawka (I977) 'From rubble to monument: the pace of recovery'. In J.E. Haas, R.W. Kates, and M.J. Bowden (eds.) Reconstruction following Disaster, MIT Press, Cambridge, MA. pp. I-23.

Kawawaki, Y., Y. Akamatsu, S. Sanjaya Bhatia, and G. Potutan (2013) The Great East Japan Earthquake 2011: Case Studies. Recovery Status Report 06. http://www.recoveryplatform.org/assets/irp_case_ studies/ENGLISH_RECOVERY\%20STATUS\%2OREPORT\%20JAPAN_revised\%2020I4.3.27.pdf (last accessed on 20 November 20I6).

Kennedy, J., J. Ashmore, E. Babister, and I. Kelman (2008) 'The meaning of "build back better": evidence from post-tsunami Aceh and Sri Lanka'. Journal of Contingencies and Crisis Management. I6(I). pp. $24-36$.

Kenny, C. (20I2) 'Build back better: great slogan, bad idea?'. I I January. http://blogs.cgdev.org/ globaldevelopment/20I2/oI/build-back-better.php (last accessed on 26 October 20I6).

Kingdom, J. (1995) Agendas, Alternatives, and Public Policies. HarperCollins College Publishers, New York, NY. 
Kirk, J. (2008) Building Back Better: Post-earthquake Responses and Educational Challenges in Pakistan. http://unesco.org.pk/eedrmu/erp/publications/Building\%2oback\%2obetter.pdf (last accessed on 26 October 20I6).

Lallemant, D. (2013) 'Building post-disaster resilience: a diagram'. I6 July. http://resilienturbanism. org/dlallemant/building-post-disaster-resilience-a-diagram/ (last accessed on 26 October 20I6).

Linnerooth-Bayer, J. and A. Amendola (2000) 'Global change, natural disasters and loss-sharing: issues of efficiency and equity'. Geneva Papers on Risk and Insurance - Issues and Practice. 25(2). pp. 203-2I9.

Linnerooth-Bayer, J. and R. Mechler (2005) Disaster Risk Financing for Developing Countries. International Institute for Applied Systems Analysis (IIASA) Presentation to the World Bank, Washington, DC, US, I7 November 2005 .

Lloyd-Jones, T. (2007) 'Building back better: how action research and professional networking can make a difference to disaster reconstruction and risk reduction'. Presentation to the RIBA Research Symposium 2007: Reflections on Practice: Capturing Innovation and Creativity, London, UK, I9 September 2007.

Lubkowski, Z., A. Crewe, A. Manafpour, and D. Grant (2010) The MW8.8 Maule, Chile, Earthquake of 27th February 2010. A preliminary field report by EEFIT. Bristol University, Bristol.

Mainichi Shimbun Weekly News (20I4) 'March I2'. http://mainichi.jp/english/ (last accessed on 22 May 20I4).

Matanle, P. (20II) 'The Great East Japan Earthquake, tsunami and nuclear meltdown: towards the (re) construction of a safe, sustainable, and compassionate society in Japan's shrinking regions'. Local Environment. I6(9). pp. 823-847.

Me-Bara, Y. and F. Valdez, Jr., (2004) 'Recovery time after a disaster and the ancient Maya'. Journal of Archaeological Science. 3I(9). pp. I3II-I324.

Meyer, P.J (20I4) Chile: Political and Economic Conditions and U.S. Relations. Io January. Congressional Research Service, Washington, DC.

MINVU (Ministerio de Vivienda y Urbanismo) (2010) Plan de Reconstrucción MINVU: Chile Unido Reconstruye Mejor. First edition (August). http://www.preventionweb.net/files/28726_plande reconstruccinminvu.pdf (last accessed on 27 October 20I6).

MINVU (20I I) Government of Chile Ministry of Housing and Urban Development Reconstruction Plan. May (firstEnglishedition).http://www.minvu.cl/incjs/download.aspx?glb_cod_nodo=20I3IO08I250I5 \&hdd_nom_archivo=Libro\%2oIngle\%C3\%ACs.pdf (last accessed on 20 November 20I6).

Murao, O. and S. Isoyama (2012) 'Transition of housing location in villages in Iwate prefecture after the Sanriku tsunamis in I896 and I933'. Paper presented to the 9 th International Conference on Urban Earthquake Engineering and the 4th Asia Conference on Earthquake Engineering, Tokyo, Japan, 6-8 March 20I2.

NHK (Nippon Hoso Kyokai) (2015) 'New challenges in the earthquake affected areas seawalls'. 25 September. http://www.nhk.or.jp/ohayou/marugoto/20I5/09/0925.html (last accessed on I2 February 20I6).

OECD (Organisation for Economic Co-operation and Development) (2013) Policy Making after Disasters: Helping Regions Become Resilient - The Case of Post-earthquake Abruzzo. OECD Publishing, Paris.

OECD (20I6) 'Gross national income'. https://data.oecd.org/natincome/gross-national-income.htm (last accessed on 20 November 20I6).

Ohsugi, S. (2010) Local Government Planning in Japan. Papers on the local governance system and its implementation in selected fields in Japan. No. I5. http://www.clair.or.jp/j/forum/honyaku/ hikaku/pdf/BunyabetsuNoisen.pdf (last accessed on 27 October 20I6).

Olshansky, R.B. (2005) 'Toward a theory of community recovery from disaster: a review of existing literature'. Paper presented to the First International Conference of Urban Disaster Reduction, Kobe, Japan, I9 January 2005. 
Olshansky, R.B. (2006) 'Planning After Hurricane Katrina'. Journal of the American Planning Association. $72(2)$. pp. I 47-I53.

Olshansky, R.B. and L.A. Johnson (2010) Clear as Mud: Planning for the Rebuilding of New Orleans. American Planning Association, Chicago, IL.

Omidvar, B., H. Zafari, and S. Derakhshan (20I0) 'Reconstruction management policies in residential and commercial sectors after the 2003 Bam earthquake in Iran'. Natural Hazards. 54(2). pp. 289-306.

Ono, Y. (2014) OECD workshop: learning from crises and fostering the continuous improvement of risk governance and management'. 30 September. http://www.slideshare.net/OECD-GOV/oecdworkshop-learning-from-crises-and-fostering-the-continuous-improvement-of-risk-governanceand-management-prof-yoichi-ono (last accessed on 27 October 20I6).

Özden, A.T. (20I4) Architecture and Disaster: A Holistic and Risk-based Building Inspection Professional Training Model for Practicing Architects in Turkey. PhD thesis. Middle East Technical University, Ankara.

Padgett, T. (20II) 'Rebuilding Chile: harder than rescuing miners?'. 4 March. http://world.time.com/ 20II/03/O4/rebuilding-chile-harder-than-rescuing-miners/ (last accessed on 27 October 20I6).

Platt, S. (2012) Reconstruction in Chile Post 2010 Earthquake. ReBuilDD Field Trip September 20 I I. http://www.carltd.com/sites/carwebsite/files/Reconstruction\%2oin\%20Chile\%2oPost\%2o 2010\%20Earthquake_o.pdf (last accessed on 27 October 20I6).

Pomonis, A. et al. (eds.) (20I3) Recovery Two Years after the 2011 Tōhoku Earthquake and Tsunami: A Return Mission Report by EEFIT. https://www.istructe.org/getattachment/resources-centre/technical-topicareas/eefit/eefit-reports/EEFIT-Japan-Recovery-Return-Mission-20I3-Report-(I).pdf.aspx (last accessed on 27 October 2016).

Ridgwell, H. (20I I) 'Japan tsunami damage cost could top \$30o billion'. VoA. 24 March. http://www. voanews.com/a/japan-tsunami-estimated-costliest-ever-disaster-I I 8644489/I3702I.html (last accessed on 20 November 20I6).

Rubin, C.B., M.D. Saperstein, and D.G. Barbee (eds.) (I985) Community Recovery from a Major Natural Disaster. FMHI Publications. Paper 87. http://scholarcommons.usf.edu/cgi/viewcontent.cgi? $\operatorname{article}=$ Io86\&context $=$ fmhi_pub (last accessed on 27 October 20I6).

Sandoval, V. and C. Gonzalez (2015) 'Examining “disaster capitalism”: post-disaster actions in Chile'. Paper presented to the 7 th International i-Rec Conference 20I5: Reconstruction and Recovery in Urban Contexts, London, UK, 6-8 July 20I5. http://www.academia.edu/I7I92529/Examining_ disaster_capitalism_post-disaster_actions_in_Chile (last accessed on 27 October 20I6).

Saraךoğlu, C. and N. Demirtaş-Milz (20I4) 'Disasters as an ideological strategy for governing neoliberal urban transformation in Turkey: insights from Izmir/Kadifekale'. Disasters. 38(I). pp. I78-20I.

Scholl, R. (I986) Reducing Earthquake Hazards: Lessons Learned from Earthquakes. Earthquake Engineering Research Institute, Oakland, CA.

Sorensen A. (2004) The Making of Urban Japan: Cities and Planning from Edo to the Twenty-first Century. Psychology Press, Hove.

Srivichai, M., S. Supharatid, and F. Imamura (2007) 'Recovery process in Thailand after the 2004 Indian Ocean tsunami'. Journal of Natural Disaster Science. 29(I). pp. 3-I2.

Tapan, M. et al. (2013) 'Failures of structures during the October 23, 20I I Tabanlı (Van) and November 9, 20 I Edremit (Van) earthquakes in Turkey’. Engineering Failure Analysis. 34 (December). pp. 606-628.

TCIP (Turkish Catastrophe Insurance Pool) (2OII) Compulsory Earthquake Insurance: Annual Report 2010. http://www.tcip.gov.tr/content/annualReport/20Io_Annual_Report_DASK.pdf (last accessed on 8 November 20I6).

Thiruppugazh, V. (200I) What has Changed after Gujarat Earthquake 2001? http://www.jst.go.jp/astf/ document/43abst.pdf (last accessed on 27 October 20I6).

Toomey, E. (2015) 'The recovery phase in post-earthquake Christchurch, New Zealand'. Paper presented to the 3 rd United Nations World Conference on Disaster Risk Reduction, Sendai, Japan, I4-I8 March 2015. 
Turan, M. (20I2) 'Lessons learnt from Van and Erciş earthquakes 20II, Turkey: an evaluation of disaster management'. International Journal of Business and Social Science. 3(22) (Special Issue-November). http://ijbssnet.com/journals/Vol_3_No_22_Special_Issue_November_2012/5.pdf (last accessed on 27 October 2016).

Üngör, M. and K. Kalafatc1lar (20I4) Productivity, Demographics and Growth in Turkey: $2004-2012$. Central Bank of the Republic of Turkey, Ankara.

USGS (U.S. Geological Survey) (2010) 'M 8.8 - Offshore Bio-Bio, Chile'. http://earthquake.usgs. gov/earthquakes/eventpage/uspoooh7rf\# executive (last accessed on 27 October 20I6).

USGS (2OII) 'Magnitude-7.2 earthquake in eastern Turkey'. http://www.usgs.gov/blogs/features/ usgs_top_story/earthquake-in-eastern-turkey/ (last accessed on 27 October 20I6).

Wu, J.Y. and M.K. Lindell (2004) 'Housing reconstruction after two major earthquakes: the I994 Northridge earthquake in the United States and the I999 Chi-Chi earthquake in Taiwan'. Disasters. 28(I). pp. 63-8I.

Ye, Y. (I996) 'Decision-making for recovery and reconstruction following a strong earthquake'. In F.Y. Cheng and Y.Y. Wang (eds.) Post-earthquake Rehabilitation and Reconstruction. Pergamon Press, Oxford. pp. 56-68. 